NBER WORKING PAPER SERIES

\title{
THE IMPACT OF FOREIGN INTEREST RATES ON THE ECONOMY: THE ROLE OF THE EXCHANGE RATE REGIME
}

\author{
Julian di Giovanni \\ Jay C. Shambaugh \\ Working Paper 13467 \\ http://www.nber.org/papers/w13467
NATIONAL BUREAU OF ECONOMIC RESEARCH
1050 Massachusetts Avenue
Cambridge, MA 02138
October 2007

\begin{abstract}
We thank Andrew Bernard, Menzie Chinn, Fabio Ghironi, Pierre-Olivier Gourinchas, Andrei Levchenko, Gian Maria Milesi-Ferretti, Romain Rancipere, Alessandro Rebucci, Tiago Ribeiro, Andy Rose, and seminar participants at the IMF, Dartmouth College, the Federal Reserve System's Board of Governors, Trinity College Dublin, University College Dublin, the NBER Monetary Economics Summer Institute, the 2006 AEA meetings, and the Federal Reserve Bank of New York for comments. Thoughtful comments by two anonymous referees and the editor, Charles Engel, also helped substantially improve the paper. All remaining errors are the responsibility of the authors. We would also like to thank Gian Maria Milesi-Ferretti for sharing data on capital controls and capital flows and Carmen Reinhart and Menzie Chinn for making their data available on their websites. Part of this research was conducted while Jay Shambaugh was a Visiting Scholar at the IMF and a Visiting Fellow at the Institute for International Integration Studies at Trinity College Dublin. The views expressed in this paper are those of the authors and should not be attributed to the International Monetary Fund, its Executive Board, its management, or the National Bureau of Economic Research.

(C) 2007 by Julian di Giovanni and Jay C. Shambaugh. All rights reserved. Short sections of text, not to exceed two paragraphs, may be quoted without explicit permission provided that full credit, including (C) notice, is given to the source.
\end{abstract}


The Impact of Foreign Interest Rates on the Economy: The Role of the Exchange Rate Regime Julian di Giovanni and Jay C. Shambaugh

NBER Working Paper No. 13467

October 2007

JEL No. F3,F4

\begin{abstract}
$\underline{\text { ABSTRACT }}$
It is often argued that many economies are affected by conditions in foreign countries. This paper explores the connection between interest rates in major industrial countries and annual real output growth in other countries. The results show that high foreign interest rates have a contractionary effect on annual real GDP growth in the domestic economy, but that this effect is centered on countries with fixed exchange rates. The paper then examines the potential channels through which major-country interest rates affect other economies. The effect of foreign interest rates on domestic interest rates is the most likely channel when compared with other possibilities, such as a trade effect.

Julian di Giovanni

International Monetary Fund

Research Department

Strategic Issues Division

700 19th Street NW

Washington DC, 20431

jdigiovanni@imf.org

Jay C. Shambaugh

Dartmouth College

Department of Economics

6106 Rockefeller Hall

Hanover, NH 03755

and NBER

jay.c.shambaugh@dartmouth.edu
\end{abstract}




\section{Introduction}

Discussions of globalization often assert that the fortunes of many countries are driven by other major economies. Conventional wisdom holds that conditions in major countries often spill over to other economies, which then experience volatility for reasons independent of domestic policies (e.g., International Monetary Fund 2007). One manifestation of this idea is that major country interest rates have a strong impact on conditions in other countries. At the same time, the open economy "trilemma" and empirical tests of it suggest that only countries with pegged exchange rate regimes give up their domestic monetary autonomy. ${ }^{1}$ This loss of autonomy then implies a potential channel through which foreign interest rates can affect pegs and floats differently, with pegs being directly affected by foreign interest rates and floats insulated from these rates. ${ }^{2}$

This paper answers two questions. First, what is the effect of interest rates in base countries on other countries' annual real GDP growth? ${ }^{3}$ Second, how does this effect vary by the exchange rate regime and other country characteristics? Answering the second question helps to disentangle the channels through which foreign country interest rates affect other economies. We find that annual real output growth in countries is negatively associated with interest rates in their base countries, but that this effect holds only for countries with fixed exchange rates. This finding holds across a wide set of specifications, a variety of controls for time and base- and domestic-country characteristics, and various sub-samples. The results are also robust to concerns of endogeneity of exchange rate regimes, as well as other simultaneity concerns, such as correlated shocks across the base and domestic countries. ${ }^{4}$ In addition, the results are presented across different empirical models (fixed effect panel and random coefficients models) and hold even more strongly when using investment growth rather than GDP growth.

The main finding thus implies that there are real costs to the loss of monetary autonomy that comes with pegging and provides further support for the hypothesis that interest rates can have substantial effects on the real economy. There may be benefits to pegging, but changing the interest rate to maintain the peg will have consequences for the economy.

\footnotetext{
${ }^{1}$ The trilemma is the conjecture that at any one time a country can pursue only two of the three following options: a fixed exchange rate, open capital markets, and monetary autonomy; this is the case because a fixed exchange rate and open capital markets will imply by interest parity that a country has lost its monetary autonomy.

${ }^{2}$ A "peg" will henceforth refer to a country whose exchange rate stays within a prescribed range, while "float" and "nonpeg" will be used interchangeably to refer to any country that is not pegged.

${ }^{3}$ The "base country" is the country to which a country pegs or the country to which it would peg if it were pegged. For nonpegs, the base is base is determined by previous pegging history, cultural and historical ties, dominant regional economies, as well as a close reading of each currency's history. See Section 3.1, Appendix $\mathrm{A}$ and Table A1 for more details.

${ }^{4}$ These issues are further discussed in Sections 2 and 3.2.2.
} 
Specifically, base-country interest rates that are 1 percentage point higher lead to a 0.20 percentage point decline in annual GDP growth in pegged countries as opposed to no change in countries with floats.

Turning to the channels underlying this result, we find that base rates have an impact on domestic interest rates and the impact is much stronger for pegs, while they do not appear to have an effect on variables such as exports to the base country. These findings, along with the differences seen across exchange rate regimes, suggest that the direct interest rate channel may be the primary channel through which base interest rates affect other countries, and are consistent with recent evidence that while many countries may show "fear of floating," interest rates in countries that actually do float show far less connection to base interest rates than countries that peg (Shambaugh 2004 and Obstfeld, Shambaugh and Taylor 2004, 2005).

This paper is related to two literatures: (i) the impact of domestic monetary policy on the economy, and (ii) the impact of major economies on other countries' business cycles. While not studying monetary policy per se, we are interested in the way interest rates affect the economy. There is an extensive literature on the impact of domestic monetary policy on the economy, which is too broad to distill here. ${ }^{5}$ One paper that is related to the present study, however, is di Giovanni, McCrary and von Wachter (2005), who use the EMS/ERM period as a quasi-experimental setting to test for the causal impact of domestic monetary policy by instrumenting other European interest rates with the German one in order to test for the impact of domestic monetary policy, and find a strong effect. ${ }^{6}$

The literature on how industrial countries affect less-developed countries' economies is also relevant. Dornbusch (1985) considers the role of large country business cycles in determining commodity prices and, subsequently, other outcomes for less-developed countries. Recently, Neumeyer and Perri (2005) analyze the role of fluctuations in domestic interest rates on the business cycle of small open economies, where the interest rate is decomposed into an international rate and a country risk component. There have also been several attempts to untangle the impact of large country interest rates on domestic annual GDP growth. Reinhart and Reinhart (2001) consider a variety of North-South links when examining Group of Three (G-3) interest rate and exchange rate volatility, and find that the U.S. real interest rate affects growth in some regions. Frankel and Roubini (2001) also find a negative effect of G-7 real interest rates on less-developed countries' output. Since these papers consider many aspects of North-South relations, they do not have space to consider in detail

\footnotetext{
${ }^{5}$ See Christiano, Eichenbaum and Evans (1999) for discussion.

${ }^{6}$ The present paper does not focus on identified monetary policy but on the total impact of foreign interest rates in order to better understand the way foreign conditions and linkages affect domestic annual GDP growth across a large set of countries.
} 
how major-country interest rates and the domestic economy are connected. In addition to these studies, there have been a number of papers that use vector autoregressions (VARs) to explore the transmission of international business cycles. ${ }^{7}$ A notable contribution is Kim (2001), who finds that U.S. interest rates have an impact on output in the other six G-7 countries. This paper is one of the few to examine the potential channels through which the interest rate has an effect. It finds virtually no trade impact and that the impact on output comes from a reduction in the world interest rate. ${ }^{8}$

What has been absent from the study of foreign rates' impact on the real economy, though, is conditioning on the role of the exchange rate regime in the transmission of the foreign interest rate on the domestic economy. ${ }^{9}$ The present paper uncovers the impact of major country interest rates on other countries while paying particular attention to the way the exchange rate regime may affect the transmission. By including a broad panel of countries that have different base countries, the present study uses time controls and focuses on the specific effect of the base interest rate. Thus, our panel allows us to strip out both individual country effects and worldwide movements in growth rates providing a better identification strategy. We confirm the results by moving beyond standard panel analysis, using a random coefficient model which allows us to use a variety of controls and test why some countries experience more of an impact from foreign interest rates. We consistently find the exchange rate regime is the factor driving the magnitude of countries' response to base interest rates. ${ }^{10}$

Section 2 describes the empirical framework and any potential bias concerns. Section 3 presents the data and results. Section 4 concludes.

\section{Empirical Framework}

\section{$2.1 \quad$ Panel Model}

We examine the direct impact of base-country interest rates on domestic annual GDP growth. The key advantage of this strategy is that it frees us from many of the estimation biases which affect the empirical literature that examines the impact of domestic interest

\footnotetext{
${ }^{7}$ See for example, Canova (2005), Maćkowiak (2003), and Miniane and Rogers (2006).

${ }^{8}$ All countries studied float their currencies against the U.S. dollar, so there is implicitly no discussion of exchange rate regime in the analysis.

${ }^{9}$ Again, there has been study of the way foreign interest rates affect local interest rates more in pegged countries. See Section 3.4.1 where we confirm these results in our data for more details. Further, Broda (2004) considers how exchange rate regimes affect the impact of terms of trade shocks.

${ }^{10}$ Our results are consistent with many other strands in the literature. The fact that only pegged economies respond to base-country interest rate changes makes sense when one considers that exchange rates tend to be quite disconnected from macroeconomic fundamentals and that uncovered interest parity does not tend to hold. For example, see Flood and Rose $(1995,1999)$ regarding the irrelevance of fundamentals for exchange rates, and Froot and Thaler (1990) for a discussion of uncovered interest parity.
} 
rates on real activity. First, the forward-looking bias concern found in the domestic monetary policy literature will be smaller in our estimates. ${ }^{11}$ Second, it is often difficult to disentangle whether the domestic interest rate drives output or vice versa - particularly for small less-developed countries (Neumeyer and Perri 2005, Uribe and Yue 2006). For example, poor fundamentals may drive up a country's borrowing costs and also slow output growth, thus placing further upward pressure on interest rates.

Further, whether the base interest rate is set with respect to base-country conditions in an expected or unexpected manner is irrelevant for the purpose of this study, since we are not examining the impact of monetary policy but the total impact of foreign interest rates. We ask what is the effect of interest rates in base countries on domestic countries' output. This question is explored by estimating the following annual output growth equation in a panel regression:

$$
y_{i t}=\alpha_{1}+\theta R_{i t}^{b}+\phi_{1}^{\prime} \mathrm{X}_{i t}+\nu_{i t}
$$

where $i$ represents a given country, $y_{i t}$ is annual real GDP growth, $R_{i t}^{b}$ is the base country nominal interest rate, and $\mathrm{X}_{i t}$ is a matrix of country fixed effects and other covariates. $R_{i t}^{b}$ varies across domestic countries since they have different base countries (see below for a further discussion). In this case, the OLS estimate of the impact of the base interest rate on domestic output growth $\left(\widehat{\theta}_{O L S}\right)$ is identified since domestic output growth will arguably not drive the base country's interest rate.

\subsubsection{Endogeneity Concerns and Common Shocks}

While less affected by the classic endogeneity issues of domestic monetary policy empirical work, there are still a number of potential endogeneity concerns. First, it is possible that domestic output could in fact drive foreign rates. For example, in a two-country model, if home productivity falls, capital will flow to the foreign country and interest rates will fall. This endogeneity, though, would lead to a positive correlation between foreign interest rates and local GDP growth, not the negative one found in this paper. We are able to address this issue by eliminating large home countries that could plausibly affect the base interest rates. There is still a possibility that world shocks influence domestic output growth and the base interest rate contemporaneously. We control for these shocks by including various controls in the $\mathrm{X}_{i t}$ matrix, such as time fixed effects. Recent tests developed by Pesaran (2004)

\footnotetext{
${ }^{11}$ The concern of this forward-looking component of monetary policy has been discussed widely (Bernanke and Blinder 1992, Bernanke and Mihov 1998, Romer and Romer 1989). Taylor (1993) is the classic paper that formulates such policy rules, which are now common in the literature. Clarida, Galí and Gertler (2000) is an early contribution in the empirical estimation of such rules. See di Giovanni et al. (2005) for a simple instrumental variable (IV) approach to identify the impact of monetary policy on output growth given a potential forward-looking bias problem.
} 
confirm that the inclusion of time fixed effects greatly decreases cross-sectional correlations of error terms to the point of insignificance in our sample. Furthermore, the endogeneity of monetary policy in the base country may also bias the estimate of $\theta$. In particular, the base interest rate may change in response to the base country policymaker's reaction to expected GDP growth, which might have a direct influence on domestic country GDP growth (i.e., on $\left.y_{i t}\right)$. This effect actually biases against finding a strong response of domestic GDP growth, so we also include base country controls in $\mathrm{X}_{i t}$. Base GDP growth also helps control for regional shocks that may hit the base and local countries jointly.

It is possible that there are non-global shocks that are not captured by base GDP growth but do affect home GDP growth and base interest rates simultaneously. We think many of these (e.g., the Asian Crisis and other financial crises) will lead to both base interest rates and domestic GDP growth decreasing, which is the opposite of what is implied by our results. However, we must still acknowledge the possibility of not capturing other shocks that could raise simultaneity concerns. We further address this issue in Section 2.2.

\subsubsection{The Role of Exchange Rate Regimes}

The second question that this paper seeks to answer is whether the impact of the base interest rate on domestic output growth varies across exchange rate regimes. This hypothesis is tested in the following regression framework:

$$
y_{i t}=\alpha_{2}+\theta_{1} R_{i t}^{b}+\theta_{2} P e g_{i t}+\gamma R_{i t}^{b} \times P e g_{i t}+\phi_{2}^{\prime} \mathrm{X}_{i t}+v_{i t},
$$

where $P e g_{i t}$ is a $0 / 1$ dummy variable indicates whether country $i$ is pegged or not to its base country. Testing the null hypothesis $\gamma=0$ will answer whether there is a difference in the impact of the base country interest rate on domestic output growth across pegs and floats. In particular, we expect that $\gamma<0$ if pegs are more affected by base-country interest rates. A matrix of controls, $\mathrm{X}_{i t}$, is also included.

The potential bias due to the endogeneity of base-country monetary policy is again a concern, but is expected to be larger for pegged countries because these economies are likely to be more dependent on the base country, thus biasing $\gamma$ towards zero. That is, if the base rate is forward looking and pegs are more connected, we are unlikely to find a significant negative $\gamma=0$. On the other hand, if high base rates slow foreign growth below its average rate, then if pegs are more connected, we might worry the pegs will appear more strongly affected. Again, including base GDP can help control for this directly. Further, we examine whether trade flows to the base country move with the base interest rate.

Finally, we address the important concern that pegs and floats are simply different and that countries that tend to peg are more affected by the base country than floats regardless 
of the exchange rate regime. We take two approaches. First, we note that most countries both float and peg at some point in the sample. Second, we drop the countries that either always peg or always float and look at the remaining sample. More rigorously, we run a probit model to predict peg status and trim the sample to exclude observations with a propensity score that does not have joint support. That is, we exclude all countries with very low probability of pegging (because pegs rarely do) and countries that are very likely to peg (because floats are rarely in that part of the distribution). This leaves a sample of observations that are quite likely to either peg or float. A final concern is that the base for floats is misidentified, leading to a weaker connection with the base interest rate for these countries. As described below, the base choice is relatively straightforward, but dropping countries that always float (where it is presumably more difficult to identify a base), or using a propensity score to more scientifically narrow the sample helps address these concerns.

\subsubsection{Methodological Details}

The growth rate of output is considered rather than a detrended level of output. First, using levels and including lagged output yields a coefficient extremely close to one on the lagged output coefficient, while not affecting our other results substantially. Given this result and potential concerns of heterogeneous dynamics across countries - see Section 2.2 - we choose the parsimonious approach of taking growth rates before running the regressions. Moreover, the use of growth rates and level of interest rates is not uncommon in the literature (Bernanke, Gertler and Watson 1997, Hamilton and Herrera 2004), as well as previous investigations of foreign interest rates' impact on the economy (Frankel and Roubini 2001, Reinhart and Reinhart 2001). Recent theoretical models also show that the output-interest rate relationship is one where the deviation of output from a trend steadystate is dependent on the interest rate (e.g., Rotemberg and Woodford 1997). ${ }^{12}$ Using GDP growth is similar in spirit to such a concept. It is also worth noting that this paper is not about long-run GDP growth, but about business cycle frequency acceleration and slowing of growth caused by base interest rates. We rely on the logic that while the interest rate is persistent, it is ultimately stationary, and thus the concern that our structure would imply that a permanently higher $R^{b}$ would lead to a permanently lower growth rate does not hold as interest rates cannot be permanently higher.

We experimented with three other detrending methods besides growth rates: (i) linear detrending, (ii) HP filtering, and (iii) band-pass filtering, which required some additional

\footnotetext{
${ }^{12}$ In a less-developed countries context, there is a literature which argues that the length and behavior of cycles may be quite different for industrial and non-industrial countries. Furthermore, shocks to trend growth are the primary source of fluctuations in non-industrial markets as opposed to transitory fluctuations around the trend (Aguiar and Gopinath 2007).
} 
backcast-forecast techniques given annual data and short samples for some countries. Applying these different detrending methods present some potential problems. First, it is not clear what set of "standard" parameter values can be plugged into different filters for emerging or developing countries. Applying these filters is also difficult given we do not always have a full 30 year sample of GDP data for many non-industrial countries (thus the need for backcast-forecast techniques to obtain reliable band-pass filtered data). Furthermore, in our main work, we drop observations due to hyperinflation or obvious outlier years. This dropping does not seem to bias our baseline growth rate regressions in any particular direction, but does create problems for filtering the data. Second, given that our analysis is static (i.e., does not incorporate lags of GDP growth or interest rates), it is not obvious that we would pick up an effect using a deviation from a "potential" 13

The standard errors are clustered at the country level. This is the most conservative clustering setup in that it increases standard errors over other choices such as simply using robust standard errors or clustering at the base-country level. The latter may be a preferable choice in that the base interest rate obviously repeats for all countries pegged to the same base. We choose to use local country clustering in part to be more conservative. Clustering allows an unspecified autocorrelation matrix removing concerns of serial correlation in the error term (see Bertrand, Duflo and Mullainathan 2004). GDP growth is persistent, but not strongly so. The autocorrelation is only 0.29. Base interest rates are more persistent, but the overall regression shows only a 0.28 serial correlation in the error. Serial correlation is even lower when time and country controls are included. Thus, the serial correlation appears low enough that clustering is a sufficient means to compensate.

The concern of heterogeneity, short time-series samples and the use of annual data also preclude us from exploring more dynamic specifications. In particular, we do not try to estimate the timing of the impact of foreign interest rates on the economy (the frequency is too coarse) but instead the general effect of foreign rates and in particular the cross-sectional difference in GDP growth's reaction to foreign rates. It is possible to show, however, that the estimated interest rate coefficient summarizes the instantaneous and historical effects of interest rates on the economy. ${ }^{14}$ The persistence of foreign rates means the current

\footnotetext{
${ }^{13}$ For example, consider a case where the domestic economy's output is above potential at period $t$ and the base country raises interest rates. In our basic framework, if the country's GDP growth falls below its average (recall we have country fixed effects), there will be a negative coefficient on the base interest rate. However, imagine the case where this slowdown is not large enough such that output drops below potential at $t$. In this case, the output gap would appear positive before and after the interest rate change, and there may not be sufficient variation in the data to pick up the negative impact. That being said, it is quite possible that output will grow slowly enough to fall below potential at $t+1$, and so on. However, we would have to include lags of output and interest rates to capture this effect. As discussed in the paper, this methodology is impractical given the use of annual data and the potential of heterogeneous dynamics.

${ }^{14}$ See di Giovanni et al. (2005) for a formal analysis.
} 
observation contains a great deal of information about the lags. Combined with the relative lack of persistence in GDP growth, this means the coefficient on the current year's interest rate encapsulates the overall effect. If we dispense with our concerns about heterogenous dynamics and include lags, we find that the coefficient on the contemporaneous interest rate drops somewhat, but the sum of current and lagged is nearly exactly equal to the coefficient we report on the contemporaneous in our tables. ${ }^{15}$ Thus, we focus on the non-dynamic results in our discussion. Finally, the question of whether the effect of foreign interest rates differs across exchange rate regimes is ultimately a cross-sectional question.

\subsection{Random Coefficients Model}

Estimation of equation (2) poses certain limitations and assumptions, which may not be optimal. First, it assumes that the impact of the base rate (and other covariates) on domestic GDP growth is homogeneous across countries at time $t$, which need not be the case. ${ }^{16}$ Second, we would like to interact the base interest rate with other potential controls, but doing so with too many variables makes the estimation and interpretation of estimated coefficients from equation (2) unwieldy. Therefore, given that the focus of the paper is to examine what cross-country characteristics matter for the impact of the base rate on domestic GDP growth, we estimate the following system of equations:

$$
\begin{aligned}
& y_{i t}=\mathbf{X}_{1 i t} \beta_{1 i}+\mathbf{R}_{i t}^{b} \beta_{2 i}+\omega_{i t} \\
& \beta_{2 i}=\mathbf{Z}_{i} \gamma+\xi_{i}
\end{aligned}
$$

where $\mathbf{X}_{1 i t}$ is a matrix of country-specific dummies, time dummies, domestic inflation, base GDP growth, and oil prices. The $\mathbf{R}_{i t}^{b}$ matrix contains the base country interest rates. A key assumption underlying equation (3) is that all the coefficients in $\beta_{1 i}$ are allowed to vary by country, except for the time dummies, which capture common shocks across countries. The coefficients for $\beta_{2 i}$ are treated as random, and are modeled as a function of country-specific covariates $\left(\mathbf{Z}_{i}\right)$ in equation (4). These covariates are country characteristics averaged over the sample period. For example, one such variables is the average of $P e g_{i t}$ over time, where a 0 would indicate never pegged vs. a value of 1 , which would indicate continuously pegged.

Equations (3) and (4) can be combined to produce a Random Coefficients Model (RCM) representation of the system:

$$
y_{i t}=\mathbf{X}_{1 i t} \beta_{1 i}+\mathbf{R}_{i t}^{b} \mathbf{Z}_{i} \gamma+\epsilon_{i t},
$$

\footnotetext{
${ }^{15}$ This is true whether we include lags only of the interest rates and interactions or include lags of all variables including the dependent variable.

${ }^{16}$ E.g., see Hsiao and Pesaran (2004) and Smith and Fuertes (2004).
} 
where $\epsilon_{i t}=\mathbf{R}_{i t}^{b} \xi_{i}+\omega_{i t}$. Thus, the coefficients in the vector $\gamma$ capture how the impact of the base rate on domestic GDP growth varies by country characteristics. ${ }^{17}$ Note that the sample is restricted so that countries must have a minimum of fifteen observations to be included in this analysis. Results are robust to including a minimum of twenty observations, but several countries are lost. We thus opt for fifteen observations given the importance of the cross-sectional dimension of the data.

This econometric technique, along with our broad data set and multiple base rates, allow us to control for world growth effects with time controls, allow country-specific responses to variables such as oil prices and base country growth that may affect countries differently, and control for local inflation and unobserved country fixed effects. Such a specification gives us far more power to isolate the impact of base interest rates on local economies than previous studies. In particular, the variable response to base GDP and oil shocks allows differential responses by each country to key world shocks as well as regional shocks. This helps control for common world shocks, shocks to the base, and allows different country responses to these shocks, thus helping to isolate the effect of the base interest rate on domestic GDP growth. 18 Also, the methodology further helps in controlling for the possibility that countries that peg are in some way different from those that float.

\section{$3 \quad$ Data and Results}

\subsection{Data}

Data sources are described in detail in Appendix A. Most financial and exchange rate data comes from the IMF's International Financial Statistics while most real economy data (GDP, trade levels, etc.) come from the World Bank's World Development Indicators. The interest rates used are short-term rates: money market or treasury bill (based on availability, see appendix). The exchange rate regime classification and base country designation are from Shambaugh (2004) and is a de facto classification, which is described in detail in the appendix. ${ }^{19}$

\footnotetext{
${ }^{17}$ Following Amemiya (1978) and Hsiao (2003), equation (5) is estimated using Feasible Generalized Least Squares (FGLS). See Appendix B for details on estimation as well as assumptions and tests of the model.

${ }^{18}$ As discussed in Section 2.1.1, it is still possible there are shocks positively correlated with base interest rates that have a negative impact on home GDP growth (in pegs but not floats) that are orthogonal to these controls.

${ }^{19}$ The base countries for pegs are obvious; the base for nonpegs, while conceivably difficult to isolate, are in fact almost equally obvious. Most countries generally only peg to one country during the sample and nearly all peg at some point, thus revealing the base. Further, those that do switch bases, tend to switch directly from one peg to another (e.g., Ireland in 1979), so no ambiguous middle float exists. For the few countries that do not peg, currency history is used and the dollar in very rare cases (Japan) where no obvious other choice exists. Two financial openness variables are used, both based on information from the IMF. One is a binary variable created by the authors (see appendix) and one a continuous variable from Chinn and Ito
} 
The sample is limited in a few ways. First, hyperinflations are eliminated as they are generally outliers for many of the dimensions of interest (for example, domestic interest rates). Second, we eliminate countries with annual GDP growth either above $20 \%$ or below $-20 \%$. We view these growth rates as either mistakes in the data or highly unusual circumstances that may cloud the results. As it turns out, moving the cutoffs or allowing these outliers in the data set does not change the results except in a few circumstances where they appear to strengthen our results. Finally, we drop countries with a population less than 250,000 as we view them as too small to be representative.

Table A1 lists our country sample and Table A2 shows simple summary statistics. The sample is divided roughly equally between pegs and nonpegs and the average growth rates of the two are nearly identical. The growth rate of pegs does exhibit a slightly higher volatility; an unconditional finding, but one consistent with subsequent work showing that annual growth rates in pegs are affected by base interest rates.

\subsection{Panel Estimation}

\subsubsection{Baseline Results}

The most basic result is obtained from estimating equation (1) for the full sample. This specification examines if, on average, countries' annual real GDP growth varies with the base country interest rate. Column 1 of Table 1 shows this result where there is a negative point estimate, but it is close to zero and not remotely statistically significant. Thus, on average, countries do not seem to be affected by the base interest rate, or at least the biases towards zero discussed above dominate any relationship. The second and third columns, though, show that there is a significant relationship for pegged countries but none for nonpegs. The fourth column pools the data and uses the interaction term to highlight the exchange rate regime effect (equation (2)). Again, there is no general effect on countries (the coefficient on Base $\mathrm{R}$ is effectively zero) and yet there is a statistically significant negative coefficient on the interaction term. Pegs' economic activity appears to slow down when the base country interest rate is high. ${ }^{20}$

These results are economically significant as well. They imply that when the base interest rate is 1 percentage point (100 basis points) higher, this cuts $0.1-0.2$ percentage points off of annual GDP growth for pegged countries. Thus, if the base is in a tight monetary policy period vs. a loose period (often up to a 500 basis point swing in interest

(2005). The sample runs from 1973-2002 for 160 countries, yielding roughly 4000 country/year observations for most specifications.

${ }^{20}$ We also note that nonpegs include many countries that are truly between pegging and floating, but are not pure pegs or countries that only peg for part of the year. This methodology should blur the distinction between the two regimes, and makes the finding of a significant difference all the more surprising. 
rates), ${ }^{21}$ this could have a full percentage point impact on pegged countries annual GDP growth while having no impact on floats. Again, these results are likely biased towards zero, and the gap should be biased down as well.

The positive coefficient on the peg variable should be interpreted carefully because the coefficient on the interaction of peg and base interest rate is negative and the base interest rate is a positive variable. The mean of the base interest rate is 0.07 , and when multiplied by the -0.18 coefficient on the interaction, we see the mean impact of a peg is zero $(0.139$ $+-0.18 \times 0.07)$. The lack of an impact on annual growth rates for a pooled sample is consistent with Husain, Mody and Rogoff (2005).

\subsubsection{Fixed Effects, Other Controls, and Endogeneity Concerns}

As discussed, omitted variables and simultaneity are a concern. In particular, world shocks may raise interest rates and slow down growth around the world, and the base country's annual GDP growth may have direct effects on the domestic country's. Table 2 explores some of these issues by including a variety of fixed effects and base-country GDP growth. First, the regression includes year effects to control for worldwide shocks and country fixed effects to control for the fact that growth rates may differ across countries, and other unobserved non-time varying country characteristics that are correlated with a country's decision to peg. ${ }^{22}$ Most data sets are unable to explore such an effect because they only use one world interest rate as opposed to a base interest rate that can vary across countries depending on the base. The base interest rates are certainly correlated, so including such year controls takes some power away from the regressions, but it leaves a much improved identification that has not previously been exploited. Column 1 shows that year and country fixed effects alter the regression slightly, but the gap between pegs and floats is close to unchanged and remains significant.

The relevant external growth factor may not be worldwide, but may be more narrow; thus, we include base GDP growth. In addition, since the empirical work is in part motivated by the interest parity relationship and the costs of borrowing, it is important to examine the real cost of borrowing in the domestic country. In this case, the local inflation rate is relevant. Column 2 of Table 2 presents our core specification. The coefficient on the gap between pegs and floats strengthens slightly to -0.17 and is significantly different from zero at 99 percent. The effect on nonpegs is zero. Base growth is positive (as expected) but insignificant (it is significant if year effects are dropped) and inflation is negative and

\footnotetext{
${ }^{21} \mathrm{~A}$ one standard deviation change within a given base country's rate is on average 320 basis points.

${ }^{22}$ In addition to the country fixed effects controlling for differences in growth across countries, we find that interacting country factors such as country size with the base rate has no impact on the results.
} 
significant.

Beyond the core specification, the interest parity relationship suggests the expected change in the exchange rate should be included, so the change in the exchange rate is included but there is no significant effect. The inflation rate is highly correlated with the GDP deflator's growth rate, and thus it may be problematic to include contemporaneous inflation. No impact is found when including lagged inflation to proxy for expected inflation, though now the change in the exchange rate is significant and negative (inflation and the change in the exchange rate are highly correlated). ${ }^{23}$ It is also noteworthy that the results change little or not at all if we drop crisis years, drop regime transition years, or drop observations that Reinhart and Rogoff (2004) describe as "freely falling." 24

As the trilemma is motivation of the study, capital controls should also be an important consideration. If a country has capital controls, its monetary policy should be less constrained by the base interest rate even if it is pegged. Thus, we include both a measure of capital openness as well as the interaction of the base interest rate and capital openness with the expectation that more open countries will be more affected by interest rates in the base country. Columns 5 and 6 of Table 2 show a weak result in this direction. Using the Chinn-Ito variable, the point estimate is negative but not significant. Using a binary coding created by the authors yields a negative coefficient significant at 90 percent. $^{25}$

While the inclusion of various fixed effects and base growth should handle many endogeneity concerns, Section 2 notes further issues. First, we confirm that large home countries are not biasing the results. Dropping observations where the home country is 10 percent the size of the base or more makes no difference to the results (dropping down to 1 percent of base still makes little difference). To examine the concern that pegs and floats may have different relationships with the base country, we drop countries that always peg or never peg. The results are even stronger for this subsample, where there is no impact for the nonpegs and a larger difference between pegs and nonpegs than Table 2's results. More formally, we use a probit model to predict pegging and eliminate observations that are almost certain to peg or not to peg. ${ }^{26}$ Trimming over a quarter of the sample until there is a clear

\footnotetext{
${ }^{23}$ Even when using lagged inflation, the change in the exchange rate is not significant if we exclude high depreciation countries (those depreciating more than $20 \%$ in a year).

${ }^{24}$ We have checked other concerns as well such as dropping all countries using the Euro and there is no effect on the results.

${ }^{25}$ Including further interactions (peg times capital openness and peg times capital openness interacted with the base rate) generates slightly stronger results on the interaction of capital openness and the base rate, but a positive coefficient on the peg times capital openness interacted with the base rate. Thus, capital openness and pegging are not purely additive nor do they both need to be active for an impact. A basic trilemma prediction would be that pegging and capital openness only matter in conjunction, but the result we find is consistent with the Obstfeld, Shambaugh and Taylor (2005) results on interest rate effects.

${ }^{26}$ One aspect of the data makes such a methodology both difficult and possibly unnecessary. This is the fact that as Juhn and Mauro (2002) note when discussing determinants of exchange rate regimes: "No result
} 
overlap in the probabilities (all observations have a probability of pegging between 0.2 and 0.6), still leaves us with results similar to Table 2. Dropping the countries that never peg or are unlikely to peg also confirms that improperly defined float bases are not driving the results.

\subsubsection{Sub-Samples}

Table 3 presents the results across different sub-samples of the data. First, the results hold in the very broad groupings of less-developed (LDC) and industrial countries (DC). In both cases, there is a significant negative relationship for the interaction term of base interest rate and pegging. There is a small and weakly significant positive coefficient on the base rate for less-developed countries in general, but this is most likely due to the omission of year effects. ${ }^{27}$ Dividing further by income groupings, there are strong significant reactions in high-income, lower-middle income, and lower-income countries. The only grouping not to show expected results is the upper-middle income. According to geographical groups, the results are strongest in the Middle East, Europe, and sub-Saharan Africa. Importantly, no region has a significant coefficient on the non-interacted base rate, so no region shows evidence of nonpegs being affected by the base rate. The results are not always significant as sample size shrinks, but it does not appear that they are driven by any one type of country or region, and they seem to be representative across a broad cross-section of countries. ${ }^{28}$

\subsubsection{Alternate Base Interest Rates}

While the results appear robust to a variety of fixed effects, we continue to explore the results by taking further advantage of the fact that countries do not all peg to the same currency. Specifically, we check non-dollar based countries against the U.S. interest rate. If who countries peg to does not matter, the dollar rate should be important as it is the major world rate, but if the effect is driven by the effect on local monetary policy as suggested

appears to be reasonably robust." Nevertheless, we control for basic optimal currency area criteria (economic size, GDP per capita, trade openness, exports to the base, distance to the base, share of exports which are fuel) and measures relating to the country (government share of the economy and financial development). Along with year effects, the predictive power in a linear probability model is not strong, but the coefficients signs are as expected. For these and other robustness tables, see Appendix C and Tables A7 and A8.

${ }^{27}$ We are unable to include year effects in these specifications because in some sub-samples there is insufficient variation in which country is the base. When we include year effects for the less-developed sample, the positive coefficient on the base rate disappears while the interaction term remains at -0.19 and is still significant.

${ }^{28}$ Much of the previous work on this topic has focused on Latin America. We note that this is the one region that comes close to having a significant reaction on the base interest rate regardless of exchange rate regime. In addition, if one does not exclude the very high inflation outliers in this region and one does not control for inflation and base GDP growth, the coefficient on base interest rate becomes significant, presenting a picture of all countries being affected by the base rate. Keeping high inflation countries in the full sample does not have this effect. 
by the trilemma, only the actual base interest rate should matter. That is, if we see a gap between pegs and floats, does this gap exist for all large foreign country interest rates, or only for the rate of the country to which they have pegged? Table 4 shows that, in the core regression, dollar-based countries and non-dollar based countries look similar, though the results are stronger for countries pegged to the dollar. Year effects cannot be included in the dollar sample in column 1 because there is only one base interest rate used. Column 2 is the analogous regression for nondollar countries. Column 3 includes year effects as well. When the U.S. interest rate is substituted for the base interest rate for the non-U.S. based countries, the only significant relationship is a positive coefficient on the non-interacted US rate. This result is again likely due to the lack of year controls (this result is not apparent in many other specifications such as the one without country fixed effects shown in column 5). There is no evidence, though, of a significant negative coefficient on the peg times the U.S. rate in any specification. Pegs do not respond negatively to the U.S. rate unless they are pegged to the dollar. These regressions show that pegs are not simply more affected by large-country interest rates, but are affected by the interest rates of their base in particular.

\subsubsection{Other Controls and Robustness Checks}

Before turning to the RCM results, we briefly summarize other controls and estimation issues we have considered. ${ }^{29}$ First, we have run regressions using a dynamic specification of equation (2). In particular, we include lagged domestic GDP growth. There is very little difference in the results, most likely because output growth is not necessarily a very persistent variable (unlike the level of GDP, for example). Real interest rates are used instead of nominal interest rates. While the rate that is relevant in interest parity or other international conditions is the nominal rate, we also examine base real interest rates. Results vary depending on how the base real interest rate is defined (subtracting current or lagged inflation from the nominal rate). Alternatively, including the base interest rate and base inflation separately continues to give our standard results. In addition, regressions are conducted across subsets of countries divided by debt levels. Least-indebted countries appear to be the least exposed to foreign interest rates, yet the core result of pegs reacting more than floats appears to hold across quartiles by debt level, though the significance varies. Furthermore, since borrowing costs are a potential channel, we check that our results hold for real investment growth in addition to real GDP growth. Results are even stronger than our main results in both size and significance. Again, there is a strong difference between pegs and nonpegs. As noted in Section 2.1.3 we also experimented with different detrending methods, but believe growth rates are the appropriate technique with annual data from a

\footnotetext{
${ }^{29}$ Refer to Appendix Tables A3-A6 for details.
} 
wide range of country types; in general, results using these other detrending measures were fragile (see the discussion in Section 2.1.3 for potential reasons). ${ }^{30}$

Finally, other exchange rate regime classifications are examined. Replicating Table 1 using de jure codes (countries' declared regime status), shows directionally similar but weaker results. This is not surprising given the fact that some of the observations are miscoded in the de jure codes mixing pegs and floats together. Using Reinhart and Rogoff's classification codes (condensed to a binary coding) yields similar, though weaker, results. ${ }^{31}$

\subsection{Random Coefficients Estimation}

We next turn to results from estimating equation (5). As discussed above, using a random coefficients framework provides a method that not only allows for greater flexibility in estimating the impact of the base interest rate on domestic annual GDP growth using the time series data while controlling for global shocks, but also allows us to take into account many cross-country controls when trying to explain this impact of the base interest rate.

This estimation methodology confirms the importance of the exchange rate regime. In particular, Table 5 presents the estimated coefficients for the whole sample and the less developed country sub-sample, respectively. ${ }^{32}$ The country-specific variables used in the regressions (i.e., the $\mathbf{X}_{1 i t}$ variables) include a constant, domestic inflation, base GDP growth, and the oil price. Furthermore, a time effect is included for all countries. We also experimented with including exchange rate changes, but, like in the panel estimation, including this variable does very little to the estimates.

Before turning to the precise quantitative results, the main result can be summarized in Figure 1. The vertical axis represents estimated coefficients of the impact of the base rate

\footnotetext{
${ }^{30}$ In particular, we obtained results closest to those for growth rates by using the band-pass filter, which yielded coefficients of the same size and sign as in our growth regressions, but were insignificant. The simple linear detrending gave results quite similar to those with growth rates, but only with more complex dynamics (including lagged base rate and its interaction with the pegged dummy, as well as lagged filtered output). Including lags raised the concern of heterogeneous dynamics, and the typical bias concerns resulting from including a lagged endogenous variable in a panel setup, which is not very easy to deal with give that our sample has large $T$ (i.e., the dynamic panel model will face issues such as weak identification, and a large number of lags will make it difficult to test for the validity of the model).

${ }^{31}$ Without fixed effects and controls results are similar, though weaker. With full effects and controls reactions are opposite our results (the base rate is weakly significantly negative and the interaction term is insignificant). Finally, we use the disaggregated Reinhart and Rogoff codes as well. Here, with no fixed effects or controls, only pegs have a significant relationship with the base interest rate and only crawling pegs have strongly significant reactions with fixed effects. The results for floating countries and freely falling countries are always close to zero and not remotely significant. Thus, the reactions are not identical across classifications, but they are similar in a number of specifications. We see an advantage in using the Shambaugh classification based on data coverage, availability, and the annual nature of the coding used which matches the frequency of our other analysis and data. Thus, we use it for the bulk of our analysis. See Shambaugh (2004) for an extensive discussion of the different classifications.

${ }^{32}$ Results were broadly consistent for the developed country sub-sample, but statistical significance is lower given a smaller cross-sectional component. Results are available from the authors upon request.
} 
on annual GDP growth, and are calculated from a first-step estimation of a FGLS procedure (see Appendix B for details). The horizontal axis represents how pegged a country was over the sample; i.e., it is an average of the exchange rate regime binary indicator over the period. A value of zero implies that the country was always a nonpeg, while a one indicates that country was always fixed to its base. The figure depicts a negative relationship, implying that the average impact of a foreign interest rate on domestic real annual GDP growth will be larger the more fixed a country is on average.

Table 5 shows that this result is robust across all specifications, and is both economically and statistically significant. The core result in column 1 indicates that foreign interest rates being 1 percentage point higher result in a 0.30 percentage point greater impact on annual real GDP growth for countries that were pegged throughout the sample compared to those that were floating, while the impact is 0.29 percentage points for the less developed country sample. This result is even larger than in the panel regressions now that multiple country characteristics are included. Given that base-country interest rates can move by up to 500 basis points over a cycle, it suggests a very large impact on pegs versus floats. The inclusion of several controls and the high statistical significance of the peg coefficient in Table 5 indicates that the results are robust. Interestingly, the majority of other control variables are not significant. However, it is worth noting that the sign of the coefficients in general line up with what one would expect.

First, the Trade/GDP coefficient is generally negative indicating that foreign interest rates have a larger impact for economies that are open to trade. There is no a priori reason to expect this result, but trade and financial openness are strongly correlated, and more financially open countries may be impacted more by foreign interest rates. Second, the impact of the base rate on domestic output growth is weaker the more a country exports to its base country (as a ratio of GDP), which makes sense given the identification problem resulting from the forward-looking bias of the foreign monetary policymaker and common shocks. ${ }^{33}$ This result is significant in columns 5 and $6 .{ }^{34}$ Income variables are not significant, except for columns 5 and 6 , where low income countries appear to be positively affected, though due to the inclusion of other variables, there are very few low income countries left in the sample in these specifications. Finally, the capital control variable (KA Open) is never significant and the point estimate is practically zero. We have experimented with other capital controls data (Chinn-Ito), and have not found any strong results for this indicator,

\footnotetext{
${ }^{33}$ Note that we also control for this effect in the time series part of the estimation by including base GDP growth in $\mathbf{X}_{1 i t}$.

${ }^{34}$ It is also interesting to note that the coefficient on the peg increases (in absolute terms) when including the exports to base variable (the specification with only the peg is not reported, but is available upon request).
} 
though the peg variable remains strong.

Financial markets, both domestic and international, may also affect how strongly the domestic economy reacts to movements in the base rate. We therefore examine the impact of the average level of financial development, external capital flows, and financial openness. Only the ratio of credit to GDP in column 4 is significant, and it has a positive coefficient, indicating that the base rate has a smaller impact in more financially developed economy (viz. credit). ${ }^{35}$

\subsection{Channels}

Foreign interest rates should not have a direct effect on the domestic economy. However, they may operate through some channel and have an indirect impact either by affecting domestic interest rates or other variables that contribute to annual GDP growth. In many ways, the channels have already been tested by examining characteristics and base rates. The result that pegs are more affected than floats is consistent with an interest rate channel. Furthermore, the fact that the exchange rate regime is the most dominant characteristic driving the relationship between base rates and GDP growth in the RCM framework is again consistent with the interest rate channel.

To further determine through which channel(s) the foreign interest rate operates, we test a series of variables against the base interest rate and see if they move in a direction consistent with the direction that GDP growth moves. If there is no relationship between a particular variable and the base interest rate, this suggests that the channel is not the driving factor behind our results. Finding significant relationships does not establish that a channel is the primary one affecting domestic growth definitively, however, but establishes the existence of a potential channel. This methodology is analogous to that of Kim (2001), who applies the same identification strategies he uses to identify the impact of monetary policy on output to other channel variables (e.g., trade). He then asks what models the resulting impulses of these variables are consistent with. We do not follow a VAR strategy to identify monetary shocks, but expect that the impact of base interest rates on economic variables to differ given potential channels, as well as across different exchange rate regimes.

\subsubsection{Domestic Interest Rate Channel}

As noted in the paper, we focus on the direct effect of base interest rates on domestic interest rates. The presumption is that domestic interest rates have some impact on the

\footnotetext{
${ }^{35}$ This result points to a potential dampening effect of financial depth on the impact of the base interest rate on annual output growth. This dampening effect of financial depth has been highlighted in recent work by Aghion, Bacchetta, Rancière and Rogoff (2006).
} 
economy, and if movements in base interest rates force movements in the local rate, this will have an impact on the economy. Thus, we test the impact of changes in base interest rates on domestic rates.

This channel has been tested in Shambaugh (2004) and Obstfeld, Shambaugh and Taylor $(2004,2005)$ with a series of controls and robustness checks. We do not repeat all tests here but simply check the basic specifications with our data. ${ }^{36}$ Table 6 shows that domestic rates do seem to move with base interest rates, but this is driven by pegs. There is no effect on floats, but the peg interaction term shows a statistically significant and economically meaningful coefficient of roughly 0.4 depending on the specification, implying that 40 percent of base rate changes are passed through to domestic rates in fixed exchange rate countries. ${ }^{37}$ Thus, the direct domestic interest rate channel appears to be a possible explanation for the growth impact. When base interest rates rise, domestic rates in pegged countries rise. The direction and difference between pegs and nonpegs are consistent with our growth results.

The change in the base rate may not simply affect the domestic rate directly, but it may also change expectations on the exchange rate and the risk premium, causing a change in the spread between the domestic and foreign rates. Uribe and Yue (2006) note that an increase in the base rate might not only increase the domestic rate directly, but may also increase the spread, generating the possibility of a more than one-for-one increase in domestic rates. ${ }^{38}$ We do not have sufficient foreign currency bond data to create true spreads, and as such, any regressions on spreads (or really just the interest rate gap) will mirror the results for interest rates. The fact that no local rate (peg or float) reacts more than one for one with the base rate suggest that the spreads over the base shrink (though more for floats). Thus, these results seem to imply there is not a strong spreads channel largely because for most countries there is no effect of base interest rates on domestic rates, and the spread is not

\footnotetext{
${ }^{36}$ Shambaugh (2004) discusses the fact that we should be worried about persistence in nominal interest rates and should consider a specification in differences. We follow that here. Domestic rates are far more persistent than the other variables we consider for channels, that is why we turn to differences only for the interest rate and spreads regressions.

${ }^{37}$ These results are also consistent with findings in Miniane and Rogers (2006) who find that local interest rates respond to base interest rates more for pegs. Borensztein, Zettelmeyer and Philippon (2001) also find pegs respond more to monetary shocks when looking at a small group of countries. Frankel, Schmukler and Servén (2004) agree that short run reactions are slower in nonpegs than in pegs, though they argue that long run reactions are more similar (cf Shambaugh). Finally, Hausmann, Gavin, Pages-Serra and Stein (1999) do not find this relationship when using a small panel of Latin American countries and using real interest rates.

${ }^{38}$ They find that the U.S. rate and the spread can explain up to $20 \%$ of domestic aggregate activity. The standard error bands on the output response to U.S. interest rate changes generally include zero and the sample size is restricted for data reasons, however. See also Neumeyer and Perri (2005). They examine the volatility of business cycles in five emerging economies, discern that real interest rate volatility contributes to the volatility of the cycle, and that both foreign rates and country risk contribute to the volatility of the real rate.
} 
acting like a multiplier of base rate changes, but is simply the residual arising from domestic rates not moving with the base rate fully.

\subsubsection{Exports to Base Channel}

The base country interest rate may also have real effects in the base country. To the extent that some countries are economically dependent on the base country, a primary channel through which this may have a direct effect on the domestic GDP growth is changes in exports to the base country. There are two reasons to be somewhat skeptical that this channel will have strong effects, however. First, to the extent that interest rates in the base countries are counter-cyclical, one would expect the classic monetary policy result that high rates are simply offsetting higher expected growth and not actually slowing the economy down to recession levels. Thus, it would be surprising to see an impact through the growth rates of the base economy. In addition, base-country GDP growth has been included in the output growth regressions, and it does not weaken the base interest rate effect. Still, we test here the impact of base rates on exports to the base country to see if there is a possibility of such a channel.

Table 6 column 2 shows that exports to the base do not move in a direction consistent with our results. Nonpegs' exports are unaffected, but there is a weakly significant increase in exports to the base by pegs. This result fits the theory that base countries may be acting counter-cyclically and this counter-cyclicality may in fact be mitigating our main results. It appears that pegs are helped by an increase in exports to the base when the base rate is high, but that this relationship is overwhelmed by the monetary channel. ${ }^{39}$

\subsubsection{Exchange Rate Change Channel}

The base interest rate will potentially move the domestic exchange rate and hence affect the economy through an exchange rate change channel. An increase in the base rate may cause the base currency to appreciate against all other currencies (that float) meaning that any floating country will depreciate against the base. Thus, we test the nominal exchange rate relative to the base country against the base interest rate. Table 6 column 3 shows the results. There are no significant reactions to the base interest rate. The peg and domestic inflation are the only significant variables. We see that pegs tend to appreciate (a negative coefficient) relative to nonpegs, though country fixed effects as well as the constant

\footnotetext{
${ }^{39}$ The exports to base/GDP series is quite persistent as well, suggesting the possibility of using changes for this channel as well. When changes in exports to base (divided by GDP) are regressed on changes in the base interest rate, there is no significant coefficient on the interaction, but the non-interacted base interest rate coefficient is now small and weakly significant positive coefficient implying that the boost in exports that comes with growing base countries may hit pegs and nonpegs alike. Regardless, this does not seem to be a channel that explains slower growth when base interest rates are high.
} 
and other controls obscure the exact pattern. Given the insignificant reaction to the base interest rate, though, this does not appear to be a primary channel. Given the general failure of uncovered interest parity to hold for floating countries, this set of results is not a surprise.

Thus, while these explorations of the channels are not intended to be definitive on any one relationship, the one effect that seems to both run in the direction that would slow annual growth and differ significantly by exchange rate regime is the impact of base rates on domestic interest rates. This finding does not establish it as the only channel, but it seems to be an important one.

\section{Conclusion}

This paper shows that while interest rates in base countries may have an effect on other countries' real economies, this impact only exists for pegged countries. Countries without a fixed exchange rate show no relationship between annual real GDP growth and the base interest rate, but countries with a fixed exchange rate grow 0.1 to 0.2 percentage points slower when base interest rates are 1 percentage point higher. The results appear robust to a wide variety of controls and specifications. Controlling for time, region, income, base country GDP growth, and other controls all present the same picture. In addition, pegged countries do not respond to any world interest rate, but only the rate of the country to which they peg - further suggesting the importance of the peg in this relationship. We have exploited variation in base rates and used RCM techniques to achieve better identification and increase confidence in the robustness of the results. As discussed in the methodology section, it is possible that shocks affect both base interest rates and local GDP growth simultaneously, but we have tried to control for these by including year effects (to capture worldwide shocks), base GDP growth (to capture real shocks in the base) and oil shocks as well as using the more flexible RCM approach.

Our work on channels suggests that the effect of the base interest rate on domestic interest rates in pegged countries is the primary channel through which this impact on GDP takes place. Pegged countries move their interest rates with the base country interest rates while floats do not. On the other hand, there does not seem to be a robust relationship consistent with the direction that growth moves between the base country interest rate and other potential channels such as the exchange rate, trade flows, and the interest rate spread over the base country.

While the fact that the fixed exchange rate countries' growth rates move with the base interest rate matches our theoretical predictions, the results are surprising on two levels. 
First, the lack of a reaction in the floating countries runs counter to conventional wisdom regarding the extent to which large country interest rates affect the rest of the world. Second, with the findings that the primary channel is the direct interest rate channel, we add to our understanding of how and why foreign country interest rates matter for pegs and demonstrate that exogenous domestic monetary policy (moving local interest rates due to a move in exogenous foreign rates) can have a palpable effect on the economy.

For many years, economists have struggled with the difficulty of finding robust macroeconomic relationships that vary across exchange rate regime. Recently, there has been additional work suggesting that monetary policy autonomy, growth, inflation, and trade may all vary with the exchange rate regime, at least to some extent. Stretching back further, Flood and Rose (1995) found a negative relationship between the exchange rate flexibility and output variability. The results here suggest that being forced to follow the base country's monetary policy even when it is not optimal for the domestic economy may cause increased volatility in GDP for fixed exchange rate countries.

These results do not suggest that pegging is either a good or bad idea, but instead add to the calculus of costs and benefits (in this case costs) an economy will face when it fixes its exchange rate. Furthermore, our results suggest that losing monetary autonomy when pegging has real impacts on the economy. Obviously, by floating, a country may expose itself to volatility owing to changes in the nominal exchange rate, but pegging does not eliminate volatility. Pegging forces a country's interest rates to follow the base country rates, which may generate more volatility in GDP by eliminating countercyclical monetary policy as an option. 


\section{References}

Aghion, Philippe, Philippe Bacchetta, Romain Rancière, and Kenneth S. Rogoff, "Exchange Rate Volatility and Productivity Growth: The Role of Financial Development," May 2006. NBER Working Paper No. 12117.

Aguiar, Mark and Gita Gopinath, "Emerging Market Business Cycles: The Cycle Is the Trend," Journal of Political Economy, February 2007, 115 (1), 69-102.

Amemiya, Takeshi, "A Note on a Random Coefficients Model," International Economic Review, October 1978, 19 (3), 793-96.

Beck, Thorsten, AslıDemirgüç-Kunt, and Ross Levine, "A New Database on Financial Development and Structure," 1999. World Bank Policy Research Working Paper No. 2146 .

Bernanke, Ben S. and Alan S. Blinder, "The Federal Funds Rate and the Channels of Monetary Transmission," American Economic Review, September 1992, 82 (4), 90121.

and Ilian Mihov, "The Liquidity Effect and Long-Run Neutrality," Carnegie Rochester Conference Series on Public Policy, December 1998, 49, 149-194.

, Mark Gertler, and Mark Watson, "Systematic Monetary Policy and the Effects of Oil Price Shocks," Brookings Papers on Economic Activity, 1997, (1), 91-142.

Bertrand, Marianne, Esther Duflo, and Sendhil Mullainathan, "How Much Should We Trust Differences-in-Differences Estimates?," Quarterly Journal of Economics, February $2004,119(1), 249-75$.

Borensztein, Eduardo, Jeromin Zettelmeyer, and Thomas Philippon, "Monetary Independence in Emerging Markets: Does the Exchange Rate Regime Make a Difference?," January 2001. IMF Working Paper No. 01/1.

Broda, Christian, "Terms of Trade and Exchange Rate Regimes in Developing Countries," Journal of International Economics, 2004, 63, 31-58.

Canova, Fabio, "The Transmission of US Shocks to Latin America," Journal of Applied Econometrics, March 2005, 20 (2), 229-51.

Chinn, Menzie D. and Hiro Ito, "What Matters for Financial Development? Capital Controls, Institutions, and Interactions," January 2005. Mimeo, University of Wisconsin and Portland State University. Revised version of NBER Working Paper No. 8967 (May 2002).

Christiano, Lawrence J., Martin Eichenbaum, and Charles L. Evans, "Monetary Policy Shocks: What Have We Learned and to What End?," in John B. Taylor and Micheal Woodford, eds., Handbook of Macroeconomics, Vol. 1A, New York: North-Holland, Elsevier, 1999, chapter 2, pp. 65-148.

Clarida, Richard, Jordi Galí, and Mark Gertler, "Monetary Policy Rules and Macroeconomic Stability: Evidence and Some Theory," Quarterly Journal of Economics, February $2000,115(1), 147-80$.

di Giovanni, Julian, Justin McCrary, and Till von Wachter, "Following the Leader: Simple Estimates of the Effect of Monetary Policy on the Economy," May 2005. IMF Working Paper No. 05/86.

Dornbusch, Rudiger, "Policy and Performance Links Between LDC Debtors and Industrial Nations," Brookings Papers on Economic Activity, 1985, (2), 303-68. 
Flood, Robert P. and Andrew K. Rose, "Fixing Exchange Rates: A Virtual Quest for Fundamentals," Journal of Monetary Economics, 1995, 36, 3-37.

and __ "Understanding Exchange Rate Volatility Without the Contrivance of Macroeconomics," Economic Journal, November 1999, 109 (459), F660-72.

Frankel, Jeffrey A. and Andrew K. Rose, "Currency Crashes in Emerging Markets: An Empirical Treatment," Journal of International Economics, November 1996, 41 (3-4), $351-66$.

and Nouriel Roubini, "The Role of Industrial Country Policies in Emerging Market Crises," December 2001. NBER Working Paper No. 8634.

, Sergio L. Schmukler, and Luis Servén, "Global Transmission of Interest Rates: Monetary Independence and Currency Regimes," Journal of International Money and Finance, September 2004, 23 (5), 701-34.

Froot, Kenneth A. and Richard H. Thaler, "Anomalies: Foreign Exchange," Journal of Economics Perspectives, Summer 1990, 4 (3), 179-92.

Hamilton, James D. and Ana Maria Herrera, "Oil Shocks and Aggregate Macroeconomic Behavior: The Role of Monetary Policy," Journal of Money, Credit, and Banking, April 2004, 36 (2), 265-86.

Hausmann, Ricardo, Michael Gavin, Carmen Pages-Serra, and Enernesto Stein, "Financial Turmoil and the Choice of the Exchange Rate Regime," 1999. IADB Working Paper No. 400.

Hsiao, Cheng, Analysis of Panel Data, 2 ed., Cambridge, UK: Cambridge University Press, 2003.

and M. Hashem Pesaran, "Random Coefficient Panel Data Models," June 2004. Mimeo, University of Southern California and University of Cambridge.

Husain, Aasim M., Ashoka Mody, and Kenneth S. Rogoff, "Exchange Rate Regime Durability and Performance in Developing Versus Advanced Economies," Journal of Monetary Economics, January 2005, 52 (1), 35-64.

International Monetary Fund, World Economic Outlook: Spillovers and Cycles in the Global Economy, Washington, D.C.: International Monetary Fund, April 2007.

, Annual Report on Exchange Arrangements and Exchange Restrictions, Washington, D.C.: International Monetary Fund. Various Issues.

Juhn, Grace and Paolo Mauro, "Long-Run Determinatns of Exchange Rate Regimes: A Simple Sensitivity Analysis," June 2002. IMF Working Paper No. 02/104.

Kim, Soyoung, "International Transmission of U.S. Monetary Policy Shocks: Evidence from VAR's," Journal of Monetary Economics, 2001, 48, 339-72.

Lane, Philip R. and Gian Maria Milesi-Ferretti, "The External Wealth of Nations: Measures of Foreign Assets and Liabilities for Industrial and Developing Countries," Journal of International Economics, December 2001, 55 (2), 263-94.

Maćkowiak, Bartosz, "External Shocks, U.S. Monetary Policy and Macroeconomic Fluctuations in Emerging Markets," February 2003. Mimeo, Humoldt University of Berlin.

Miniane, Jacques and John H. Rogers, "Capital Controls and the International Transmission of U.S. Money Shocks," 2006. Forthcoming, Journal of Money, Credit and Banking. 
Neumeyer, Pablo A. and Fabrizio Perri, "Business Cycles in Emerging Economies: The Role of Interest Rates," Journal of Monetary Economics, March 2005, 52 (2), 345-80.

Obstfeld, Maurice, Jay C. Shambaugh, and Alan M. Taylor, "Monetary Sovereignty, Exchange Rates, and Capital Controls: The Trilemma in the Interwar period," IMF Staff Papers, Special Issue 2004, 51, 75-108.

__ _ _ and __ , "The Trilemma in History: Tradeoffs among Exchange Rates, Monetary Policies, and Capital Mobility," Review of Economics and Statistics, August $2005,8^{r y}(3), 423-38$.

Pesaran, M. Hashem, "General Diagonist Tests for Cross Section Dependence in Panels," June 2004. Mimeo, University of Cambridge.

Reinhart, Carmen M. and Kenneth S. Rogoff, "The Modern History of Exchange Rate Arrangements: A Reinterpretation," Quarterly Journal of Economics, February 2004, $119(1), 1-48$. and Vincent Raymond Reinhart, "What Hurts Most? G-3 Exchange Rate or Interest Rate Volatility," October 2001. NBER Working Paper No. 8535.

Romer, Christina D. and David H. Romer, "Does Monetary Policy Matter? A New Test in the Spirit of Friedman and Schwartz," in Oliver J. Blanchard and Stanley Fischer, eds., NBER Macroeconomics Annual 4, Cambridge, Mass.: The MIT Press, 1989, pp. 121-170.

Rotemberg, Julio J. and Michael Woodford, "An Optimization-Based Econometric Model for the Evaluation of Monetary Policy," in Ben S. Bernanke and Julio Rotemberg, eds., NBER Macroeconomics Annual, Vol. 12, Cambridge, Mass,: MIT Press, 1997, pp. 297-346.

Shambaugh, Jay C., "The Effects of Fixed Exchange Rates on Monetary Policy," Quarterly Journal of Economics, 2004, 119 (1), 301-52.

Smith, Ron P. and Ana-Maria Fuertes, "Panel Time-Series," April 2004. Mimeo, Birkbeck College, London and Sir John Cass Business School, City University, London.

Taylor, John B., "Discretion Versus Policy Rules in Practice," Carnegie Rochester Conference Series on Public Policy, December 1993, 93, 195-214.

Uribe, Martín and Vivian Z. Yue, "Country Spreads and Emerging Countries: Who Drives Whom?," Journal of International Economics, June 2006, 69 (1), 6-36. 


\section{Appendix A Data Appendix}

The exchange rate regime classification comes from Shambaugh (2004) and is described there in detail. In short, a country is classified as pegged if its official nominal exchange rate stays within $\pm 2 \%$ bands over the course of the year against the base country. The base country is chosen based on the declared base, the history of a countries' exchange rate, by comparing its exchange rate to a variety of potential bases, and by looking at regional dominant currencies. In addition, single year pegs are eliminated as they more likely represent a random lack of variation rather than a true peg. Finally, realignments, where a country moves from one peg level to another with an otherwise constant exchange rate are also considered pegs. Nonpegs are also assigned a base determined by the country they peg to when they are pegging at other times in the sample. While we typically use the term "nonpeg" and the more colloquial "float" interchangeably, any country/year observation not coded as a peg is considered a nonpeg, so they are not all pure floats, but include all sorts of nonpegged regimes. Shambaugh makes extensive comparisons of this methodology and other classifications. The de jure measure is based on the IMF Annual Report on Exchange Rate Arrangements compiled in Shambaugh and extended by the authors. The Reinhart-Rogoff classification is from Reinhart and Rogoff (2004) and is available on Carmen Reinhart's website. Their coding uses parallel market data and assesses the conditional probability an exchange rate will move outside a certain range over a five year window. See Reinhart and Rogoff for more detail. In some specifications, we collapse the five-way classification into a binary one, considering all observations that are not coded pegs as nonpegs.

There are two financial openness variables used. One is the financial openness variable as defined by Chinn and Ito (2005). This is a continuous index based on information across four major categories of restrictions in the IMF Annual Report on Exchange Rate Arrangements. The other variable, is a binary indicator created by the authors based on data from the IMF Annual Report on Exchange Rate Arrangements line E2, which signifies "restrictions on payments for capital transactions." For 1973-95, we begin with data provided by Gian Maria Milesi-Ferretti and augment it with data from Shambaugh (2004). After 1995, the IMF stopped reporting this series and reported disaggregated information. The series is extended for 1996-2002 using changes in the disaggregated coding and descriptions in the yearbook to determine changes in the binary codes. Shambaugh discusses the coding in more detail including the fact that this series is highly correlated with other more detailed or disaggregated measures.

Our financial flows and debt variables are updated data from Lane and Milesi-Ferretti (2001). The Credit/GDP variable is defined as private credit by banks and other Financial institutions to GDP, and comes from the updated financial Development and Structure database of Beck, Demirgüç-Kunt and Levine (1999), which can be found at http://econ. worldbank.org.

The rest of the macroeconomic data come from standard sources. Real GDP, oil prices, M2/GDP, Trade/GDP, income levels, and regional and income dummies come from the World Development Indicators database of the World Bank. Exchange Rates and inflation come from the International Monetary Fund's International Financial Statistics database. Interest rates are from the IFS as well as Datastream and Global Financial Database. The interest rates used are short term rates, either money market or short term treasury bill. Which rate is used depends on availability with money market used as a default if both are available (the two are highly correlated). When local rates are regressed on base rates, we are careful to match local and base rates to be the same type. Exports to the base country are derived from the IMF Direction of Trade Statistics. 


\section{Appendix B Estimation of RCM Model}

The RCM regression presented in Section 2.2, equation (5), can be re-written in the following matrix notation:

$$
\mathrm{y}=\mathbf{X}_{1} \beta_{1}+\mathbf{X}_{2} \mathbf{Z} \gamma+\epsilon,
$$

where the matrices are as follows for $N$ countries over $T$ time periods:

$$
\begin{gathered}
\mathrm{y}=\underbrace{\left(\begin{array}{c}
\mathrm{y}_{1} \\
\vdots \\
\mathrm{y}_{N}
\end{array}\right)}_{N T \times 1}, \quad \mathbf{X}_{1}=\underbrace{\left(\begin{array}{cccc}
\mathrm{YEAR} & \mathbf{X}_{11} & 0 & 0 \\
\vdots & 0 & \ddots & 0 \\
\mathrm{YEAR} & 0 & 0 & \mathbf{X}_{1 N}
\end{array}\right)}_{N T \times(T+N \times K 1)}, \\
\mathbf{X}_{2}=\underbrace{\left(\begin{array}{ccc}
\mathbf{X}_{21} & 0 & 0 \\
0 & \ddots & 0 \\
0 & 0 & \mathbf{X}_{2 N}
\end{array}\right)}_{\beta_{1}}, \mathbf{Z}=\underbrace{\left(\begin{array}{c}
\beta_{\mathrm{YEAR}} \\
\beta_{11} \\
\vdots \\
\beta_{1 N}
\end{array}\right)}_{N \times N}, \quad \underbrace{\left(\begin{array}{c}
\mathbf{Z}_{1} \\
\vdots \\
\mathbf{Z}_{N}
\end{array}\right)}_{(T+N \times K 1) \times 1}, \quad \epsilon=\underbrace{\left(\begin{array}{c}
\epsilon_{1} \\
\vdots \\
\epsilon_{N}
\end{array}\right)}_{N T \times 1},
\end{gathered}
$$

and note that $\beta_{2}=\mathbf{Z} \gamma+\xi$ and that $\epsilon=\mathbf{X}_{2} \xi+\omega$.

The vector y contains output growth, $\mathbf{X}_{1}$ is a matrix of year dummies (YEAR) and country-specific variables that vary over time (e.g., base country output growth, inflation, oil price, etc.) and a country-specific intercept, $\mathbf{X}_{2}$ is a matrix of base country interest rates, and $\mathbf{Z}$ is matrix of country variables that are averaged over the sample period (e.g., the average time a country is pegged, or has capital controls). By making parts of $\mathbf{X}_{1}$ and $\mathbf{X}_{2}$ block-diagonal, we allow country dynamics to be heterogenous. ${ }^{40}$ Finally, the coefficient matrix of interest, $\gamma$, relates country "fundamentals" $(\mathbf{Z})$ to the average dynamic impact of the base country interest rate $\left(\mathbf{X}_{2}\right)$ on output growth $(\mathrm{y})$. The null hypothesis is that this impact will be negative for countries that are pegged more on average: $\gamma_{1}<0$.

We assume that $\omega$ and $\xi$ are both independent, normally distributed errors with mean zero, and are independent of each other. The main reason for making these assumptions is tractability in the estimation procedure. Imposing a common coefficient on year effects helps alleviate any cross-country correlation arising from global shocks in the $\omega$ vector. ${ }^{41}$ Furthermore, including these dummies and the impact of oil prices also helps alleviate autocorrelation in the errors of $\omega$. By forcing $\xi$ to be distributed independently across sections and homoscedastic, we are assuming that the $\beta_{2, i}$ 's are uncorrelated across countries, and have a constant variance. Inspection and tests of the covariance matrix of equation (4)

\footnotetext{
${ }^{40}$ Tests of coefficient homogeneity rejected the null hypothesis of equality.

${ }^{41}$ See Hsiao and Pesaran (2004), Section 9, on the difficulties of modeling cross-section correlation when $N$ is large $(>10)$ and for a discussion on other possible ways to model cross-section correlation in a RCM set-up. Note that a SURE framework would not work since $N>T$ in our sample. Furthermore, including common year effects greatly alleviates cross-sectional correlation as in the panel regressions according to the test statistics developed by Pesaran (2004).
} 
indicate that these are reasonable assumptions to make. Finally, assuming that $\omega$ and $\xi$ are independent implicitly assumes that the dynamic and cross-sectional error structures are uncorrelated, which is standard in panel analysis. Many of these assumptions can be relaxed by using GMM estimation techniques, but would result in a loss of efficiency.

Given the assumptions made on the error structure, one can easily apply a two-step FGLS estimation technique based on Amemiya (1978), and found in Hsiao (2003). In particular, first regress y on $\mathbf{X}_{1}$ and $\mathbf{X}_{2}$ and calculate a variance-covariance matrix, $\Sigma_{1}$. Next, take the estimated country-specific base rate coefficients, $\widehat{\beta}_{2}$, and regress these on $\mathbf{Z}$ to produce OLS estimates of $\gamma, \widehat{\gamma}_{O L S}{ }^{42}$ The variance-covariance matrix, $\Sigma_{2}$, of these estimates is then calculated taking into account the uncertainty of the estimated base rate coefficients from the first regression. The final output of this first-step procedure is a total variance-covariance matrix, which is the sum of the two variance-covariance matrices $\left(\Sigma_{1}+\Sigma_{2}\right)$ and is block diagonal. This matrix captures the uncertainty of the estimated $\beta$ and $\gamma$ coefficients. The second-step of the procedure is to estimate equation (B.1) by weighting with this total variance-covariance matrix. This estimation produces the most efficient estimates of $\gamma, \widehat{\gamma}_{G L S}$, and $\widehat{\beta}_{1}, \widehat{\beta}_{1 G L S}$.

\section{Appendix C Trimming the Sample Based on the Probability of Pegging}

As noted in the paper, one concern with the results may be that pegs and nonpegs are simply different, and that one difference may be that pegs are more tied to the base economy in some way. This appendix examines attempts to trim the sample in order to control for this problem.

First, we note that most countries peg and float in the sample; thus, pegs and floats are not set in stone and always separate. There are 152 countries in the full regressions in Table 2. If we cut all full pegs (26 countries) and full floats (30 countries) we are left with 96 countries. Column 1 of Table A7 reproduces column 2 of Table 2 (our core specification) for comparison purposes. If we drop countries that always peg and float, our results are in fact stronger, with $\gamma$ increasing to -0.21 and still no impact on nonpegs.

We also use a propensity score to restrict the sample. First, we estimate a probit model to predict peg status. Next, we drop observations that have almost no likelihood of pegging or floating, focusing instead on the middle of the propensity score distribution where countries might peg or float. As noted in the text, the exchange rate regime choice literature is not particularly successful at finding robust patterns in the data. Still, we can follow Juhn and Mauro (2002) and add optimal currency area variables as well as variables regarding the government role in the economy, financial depth, and capital controls. We do not add macro variables as they are quite likely outcomes not determinants. Year effects are also included to capture changes in the probability of pegging over time.

Table A8 shows both a linear probability model (estimated with OLS) and a probit, where the predicted values are capped to stay between zero and one. The $R^{2}$ is only 0.11 , so the predictive power is not strong. However, coefficients are reasonable in sign: richer, more closed, more financially developed countries are less likely to peg. Countries with large fuel exports, tied to the base country, closer to the base country, with more government intervention tend to peg more often. Many coefficients are not statistically significant when clustering the standard errors appropriately, and size of the economy (GDP) never is. One reason for the low predictive power is that the explanatory variables are relatively time invariant, but the same countries move back and forth between pegging and not pegging.

\footnotetext{
${ }^{42}$ It is these estimated $\gamma$ that are plotted against the average peg variables $\left(\mathbf{Z}_{1}\right)$ in Figure 1.
} 
It is quite easy to say that Belgium is more likely to peg to Germany than it is to Japan, but harder to say whether it will peg to Germany in 1982 vs. 1985.

Figure A1 shows the density of the probability of pegging for pegs and floats. The figure itself is informative. It shows that while the tails of the distributions for pegs and floats are different, in general, pegs and floats are not too different. In fact, the median score for pegs is 0.45 and for floats is 0.35 . These are not radically different types of countries. To confirm that the tails are not driving our results, we take the 5th percentile in the distribution of pegs $(0.21)$ to be the mark below which pegs rarely occur and the 95th percentile $(0.64)$ for floats to be the point above which floats rarely occur. As the figure shows, within those bounds, we have a fair overlap of the distributions. Restricting the sample here drops over $\frac{1}{4}$ of the sample, but the results are close to our core regression. Column 3 shows our core regression for the sample for which we have data to estimate the probit. Results are effectively the same as column 1 . Column 4 shows that after restricting the sample based on propensity scores, our results are quite similar to before. $\gamma$ is slightly closer to zero, but still significant and there is still no statistically significant relationship for nonpegs. Trimming the sample less aggressively (at the lower and upper 1 percentage points of the distribution, 0.16 and 0.76 , respectively) eliminates $7 \%$ of the sample, and the results are almost entirely unchanged. There is a fair bit of support in both distributions at the 1 percent mark, suggesting that is probably the appropriate place to limit the sample. Moving our cutoffs further in than the 5th percentiles begins to eliminate large parts of the sample (as can be seen from the figure).

We view these results as supportive of the contention that our core results are not being driven by a bias stemming from the choice of the exchange rate regime. Furthermore, as noted in the paper, by dropping countries that never peg or are highly unlikely to peg, we have eliminated countries for whom the designated base may be a bad match (either may be incorrectly assigned or may simply be a country to which the home country is unlikely to peg). This makes it less likely that results are driven by inappropriately selecting the base for floating countries. 
Table 1. The Effects of the Base Interest Rate on Real Output Growth: Baseline Least Square Estimates

\begin{tabular}{lcccc}
\hline \hline & $(1)$ & $(2)$ & $(3)$ & $(4)$ \\
& Full Sample & Nonpegs & Pegs & Full Sample \\
\hline Base R & -0.046 & 0.046 & $-0.137^{* *}$ & 0.046 \\
& $(0.032)$ & $(0.039)$ & $(0.044)$ & $(0.039)$ \\
Base R $\times$ Peg & & & & $-0.183^{* *}$ \\
& & & & $(0.055)$ \\
Peg & & & & $0.014^{* *}$ \\
& & & & $(0.004)$ \\
Constant & $0.036^{* *}$ & $0.030^{* *}$ & $0.043^{* *}$ & $0.030^{* *}$ \\
& $(0.002)$ & $(0.003)$ & $(0.003)$ & $(0.003)$ \\
\hline Observations & 3831 & 2078 & 1753 & 3831 \\
$R^{2}$ & 0.001 & 0.001 & 0.009 & 0.005 \\
\hline
\end{tabular}

Notes: The table gives OLS estimates of the effect of the base country nominal interest rate on annual real economic growth. The sample period is 1973-2002. Estimates in columns (1)-(4) do not include any additional controls. Robust standard errors are clustered at the country level. + significant at $10 \%$; significant at $5 \% ;{ }^{* *}$ significant at $1 \%$. 
Table 2. The Effects of the Base Interest Rate on Real Output Growth: Additional Controls

\begin{tabular}{|c|c|c|c|c|c|c|}
\hline & $(1)$ & $(2)$ & $(3)$ & $(4)$ & $(5)$ & $(6)$ \\
\hline Base $\mathrm{R}$ & $\begin{array}{l}-0.046 \\
(0.045)\end{array}$ & $\begin{array}{l}-0.014 \\
(0.046)\end{array}$ & $\begin{array}{l}-0.015 \\
(0.046)\end{array}$ & $\begin{array}{c}-0.019 \\
(0.047)\end{array}$ & $\begin{array}{c}-0.042 \\
(0.047)\end{array}$ & $\begin{array}{c}-0.011 \\
(0.048)\end{array}$ \\
\hline Base $\mathrm{R} \times \mathrm{Peg}$ & $\begin{array}{c}-0.137^{*} \\
(0.053)\end{array}$ & $\begin{array}{c}-0.174^{* *} \\
(0.050)\end{array}$ & $\begin{array}{c}-0.171^{* *} \\
(0.050)\end{array}$ & $\begin{array}{c}-0.168^{* *} \\
(0.049)\end{array}$ & $\begin{array}{c}-0.143^{* *} \\
(0.050)\end{array}$ & $\begin{array}{r}-0.159^{* *} \\
(0.049)\end{array}$ \\
\hline Peg & $\begin{array}{l}0.010^{*} \\
(0.004)\end{array}$ & $\begin{array}{c}0.011^{* *} \\
(0.004)\end{array}$ & $\begin{array}{l}0.011^{*} \\
(0.004)\end{array}$ & $\begin{array}{l}0.010^{*} \\
(0.004)\end{array}$ & $\begin{array}{c}0.006 \\
(0.004)\end{array}$ & $\begin{array}{l}0.009^{*} \\
(0.004)\end{array}$ \\
\hline Inflation & & $\begin{array}{c}-0.029^{* *} \\
(0.007)\end{array}$ & $\begin{array}{c}-0.024^{*} \\
(0.011)\end{array}$ & & $\begin{array}{l}-0.011 \\
(0.012)\end{array}$ & $\begin{array}{c}-0.023^{*} \\
(0.011)\end{array}$ \\
\hline Lagged Inflation & & & & $\begin{array}{c}0.000 \\
(0.001)\end{array}$ & & \\
\hline Base GDP Growth & & $\begin{array}{c}0.113 \\
(0.076)\end{array}$ & $\begin{array}{c}0.112 \\
(0.076)\end{array}$ & $\begin{array}{c}0.117 \\
(0.080)\end{array}$ & $\begin{array}{l}0.165^{*} \\
(0.080)\end{array}$ & $\begin{array}{l}0.139+ \\
(0.075)\end{array}$ \\
\hline$\Delta \mathrm{NER}$ & & & $\begin{array}{l}-0.008 \\
(0.009)\end{array}$ & $\begin{array}{c}-0.024^{* *} \\
(0.007)\end{array}$ & $\begin{array}{r}-0.020+ \\
(0.011)\end{array}$ & $\begin{array}{c}-0.008 \\
(0.009)\end{array}$ \\
\hline KA Open & & & & & & $\begin{array}{c}0.015^{* *} \\
(0.005)\end{array}$ \\
\hline Base $\mathrm{R} \times \mathrm{KA}$ Open & & & & & & $\begin{array}{r}-0.119+ \\
(0.063)\end{array}$ \\
\hline KA Open (Chinn-Ito) & & & & & $\begin{array}{l}0.003^{*} \\
(0.002)\end{array}$ & \\
\hline Base $\mathrm{R} \times \mathrm{KA}$ Open $(\mathrm{C}-\mathrm{I})$ & & & & & $\begin{array}{l}-0.010 \\
(0.021)\end{array}$ & \\
\hline Observations & 3831 & 3419 & 3415 & 3385 & 3117 & 3380 \\
\hline$R^{2}$ & 0.177 & 0.204 & 0.203 & 0.197 & 0.210 & 0.205 \\
\hline
\end{tabular}

Notes: The table gives OLS estimates of the effect of the base country nominal interest rate on annual real economic growth. The sample period is 1973-2002. Country and year effects are included. Robust standard errors are clustered at the country level. + significant at $10 \% ;{ }^{*}$ significant at $5 \% ; * *$ significant at $1 \%$. 
Table 3. The Effects of the Base Interest Rate on Real Output Growth: Sub-Samples of the Data

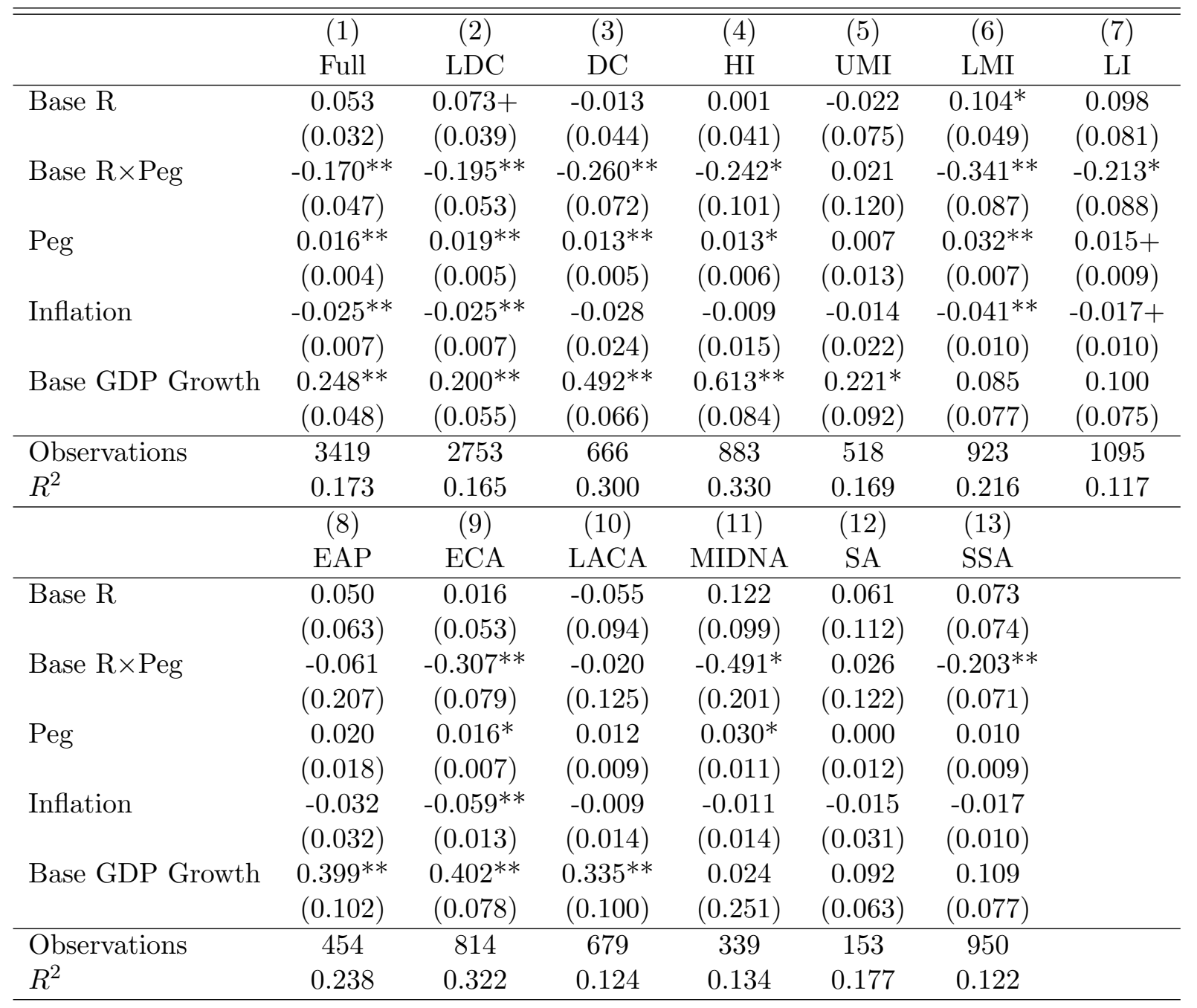

Notes: The table gives OLS estimates of the effect of the base country nominal interest rate on annual real economic growth. The sample period is 1973-2002. The estimates are based on specification (2) of Table 2, and include country, but no year effects. The following country classifications are used LDC (less developed), DC (developed/industrial), HI (high income), UMI (upper middle income), LMI (lower middle income), LI (lower income), EAP (East Asia and Pacific), ECA (Europe and Central Asia), LACA (Latin America and the Carribean), MIDNA (Middle East and North Africa), SA (South Asia), and SSA (Sub Sahara Africa). Classifications based on World Development Indicators. Robust standard errors are clustered at the country level. + significant at $10 \%{ }^{*}$ significant at $5 \% ; * *$ significant at $1 \%$. 
Table 4. Considering Non-Base Interest Rates

\begin{tabular}{|c|c|c|c|c|c|}
\hline & $\begin{array}{c}(1) \\
\text { Dollar }\end{array}$ & $\begin{array}{c}(2) \\
\text { Non-Dollar }\end{array}$ & $\begin{array}{c}(3) \\
\text { Non-Dollar }\end{array}$ & $\begin{array}{c}(4) \\
\text { Non-Dollar }\end{array}$ & $\begin{array}{c}(5) \\
\text { Non-Dollar }\end{array}$ \\
\hline Base $\mathrm{R}$ & $\begin{array}{l}0.083+ \\
(0.047)\end{array}$ & $\begin{array}{l}-0.035 \\
(0.045)\end{array}$ & $\begin{array}{c}0.031 \\
(0.060)\end{array}$ & & \\
\hline Base $\mathrm{R} \times \mathrm{Peg}$ & $\begin{array}{l}-0.198^{*} \\
(0.076)\end{array}$ & $\begin{array}{l}-0.116^{*} \\
(0.058)\end{array}$ & $\begin{array}{l}-0.127^{*} \\
(0.060)\end{array}$ & & \\
\hline Peg & $\begin{array}{c}0.020^{* *} \\
(0.006)\end{array}$ & $\begin{array}{c}0.005 \\
(0.005)\end{array}$ & $\begin{array}{c}0.006 \\
(0.005)\end{array}$ & $\begin{array}{c}0.004 \\
(0.006)\end{array}$ & $\begin{array}{c}0.000 \\
(0.006)\end{array}$ \\
\hline U.S. R & & & & $\begin{array}{l}0.091^{*} \\
(0.042)\end{array}$ & $\begin{array}{c}0.054 \\
(0.046)\end{array}$ \\
\hline U.S. $\mathrm{R} \times$ Peg & & & & $\begin{array}{l}-0.043 \\
(0.065)\end{array}$ & $\begin{array}{l}-0.028 \\
(0.075)\end{array}$ \\
\hline Inflation & $\begin{array}{c}-0.027^{* *} \\
(0.008)\end{array}$ & $\begin{array}{l}-0.014 \\
(0.020)\end{array}$ & $\begin{array}{l}-0.031 \\
(0.021)\end{array}$ & $\begin{array}{l}-0.020 \\
(0.020)\end{array}$ & $\begin{array}{l}-0.013 \\
(0.019)\end{array}$ \\
\hline Base GDP Growth & $\begin{array}{c}0.191^{* *} \\
(0.064)\end{array}$ & $\begin{array}{l}0.326^{* *} \\
(0.069)\end{array}$ & $\begin{array}{c}0.184 \\
(0.121)\end{array}$ & & \\
\hline U.S. GDP Growth & & & & $\begin{array}{c}0.243^{* *} \\
(0.068)\end{array}$ & $\begin{array}{c}0.245^{* *} \\
(0.067)\end{array}$ \\
\hline Constant & $\begin{array}{c}0.025^{* *} \\
(0.004)\end{array}$ & $\begin{array}{c}0.031^{* *} \\
(0.004)\end{array}$ & $\begin{array}{c}0.036^{* *} \\
(0.008)\end{array}$ & $\begin{array}{c}0.021^{* *} \\
(0.005)\end{array}$ & $\begin{array}{c}0.024^{* *} \\
(0.005)\end{array}$ \\
\hline Country FE & yes & yes & yes & yes & no \\
\hline Year FE & no & no & yes & no & no \\
\hline $\begin{array}{l}\text { Observations } \\
R^{2}\end{array}$ & $\begin{array}{l}2065 \\
0.176\end{array}$ & $\begin{array}{c}1354 \\
0.190\end{array}$ & $\begin{array}{c}1354 \\
0.236\end{array}$ & $\begin{array}{c}1406 \\
0.174\end{array}$ & $\begin{array}{c}1406 \\
0.016\end{array}$ \\
\hline
\end{tabular}

Notes: The table gives OLS estimates of the effect of the base country nominal interest rate on annual real economic growth. The sample period is 1973-2002. Estimates in columns (1)-(5) do not include any additional controls. Robust standard errors are clustered at the country level. + significant at $10 \%$; significant at $5 \% ; * *$ significant at $1 \%$. 
Table 5. Explanation of Base Interest Rate Impact on Real Output Growth: Random Coefficients Model

\begin{tabular}{|c|c|c|c|c|c|c|}
\hline & \multirow{2}{*}{$\begin{array}{c}\text { Full } \\
(1)\end{array}$} & \multirow{2}{*}{$\begin{array}{c}\text { LDC } \\
(2)\end{array}$} & \multicolumn{4}{|c|}{ Full } \\
\hline & & & $(3)$ & $(4)$ & $(5)$ & $(6)$ \\
\hline \multirow[t]{2}{*}{ Peg } & $-0.301^{*}$ & $-0.287^{*}$ & $-0.450^{*}$ & $-0.289^{*}$ & $-0.467^{* *}$ & $-0.448^{* *}$ \\
\hline & $(0.114)$ & $(0.119)$ & $(0.158)$ & $(0.122)$ & $(0.149)$ & $(0.142)$ \\
\hline \multirow[t]{2}{*}{ KA Open } & 0.045 & -0.089 & 0.041 & 0.165 & -0.140 & -0.164 \\
\hline & $(0.148)$ & $(0.181)$ & $(0.201)$ & $(0.167)$ & $(0.160)$ & $(0.151)$ \\
\hline \multirow[t]{2}{*}{ Trade/GDP } & -0.113 & -0.230 & -0.219 & -0.184 & -0.269 & -0.270 \\
\hline & $(0.121)$ & $(0.164)$ & $(0.205)$ & $(0.140)$ & $(0.196)$ & $(0.183)$ \\
\hline \multirow[t]{2}{*}{ Exports to Base/GDP } & 0.796 & 0.561 & 1.367 & 0.701 & $2.104+$ & $1.941+$ \\
\hline & $(0.822)$ & $(0.824)$ & $(1.100)$ & $(0.848)$ & $(1.033)$ & $(1.026)$ \\
\hline \multirow[t]{2}{*}{ High Income } & -0.106 & & -0.065 & -0.278 & -0.049 & -0.051 \\
\hline & $(0.140)$ & & $(0.208)$ & $(0.169)$ & $(0.138)$ & $(0.135)$ \\
\hline \multirow[t]{2}{*}{ Lower Mid Income } & -0.115 & & 0.053 & -0.092 & 0.086 & 0.068 \\
\hline & $(0.135)$ & & $(0.173)$ & $(0.140)$ & $(0.137)$ & $(0.136)$ \\
\hline \multirow[t]{2}{*}{ Low Income } & -0.123 & & 0.094 & -0.083 & $0.548^{*}$ & $0.509^{*}$ \\
\hline & $(0.141)$ & & $(0.190)$ & $(0.153)$ & $(0.218)$ & $(0.218)$ \\
\hline \multicolumn{2}{|l|}{ Real GDP per capita } & $\begin{array}{c}0.000 \\
(0.000)\end{array}$ & & & & \\
\hline M2/GDP & & & $\begin{array}{c}0.002 \\
(0.003)\end{array}$ & & & \\
\hline Credit/GDP & & & & $\begin{array}{l}0.517+ \\
(0.239)\end{array}$ & & \\
\hline Liab/GDP & & & & & $\begin{array}{c}0.012 \\
0.088)\end{array}$ & \\
\hline \multirow[t]{2}{*}{ NFA/GDP } & & & & & & -0.088 \\
\hline & & & & & & $(0.129)$ \\
\hline Observations & 2681 & 1936 & 2233 & 2477 & 1637 & 1662 \\
\hline Countries & 99 & 73 & 86 & 92 & 59 & 60 \\
\hline$R_{\text {whole }}^{2}$ & 0.369 & 0.348 & 0.374 & 0.386 & 0.449 & 0.451 \\
\hline$R_{\beta_{2}}^{2}$ & 0.135 & 0.151 & 0.163 & 0.182 & 0.331 & 0.350 \\
\hline
\end{tabular}

Notes: The table give the RCM estimates of the coefficients $\widehat{\gamma}$ from the model $y_{i t}=\mathrm{X}_{\mathbf{1}} \beta_{1 i}+\mathrm{X}_{2} \mathrm{Z}_{i} \gamma+\epsilon_{i t}$, where $\mathrm{X}_{1}$ is a matrix containing country specific intercepts, base country GDP growth, real oil prices, and a matrix of year dummies, $\mathrm{X}_{2}$ is a matrix of base country interest rates, and $\mathrm{Z}_{i}$ is a matrix of the variables in the table, which have been averaged over the sample period per country. 'Full' refers to the full sample of countries and 'LDC' refers to less developed countries. $R_{\text {whole }}^{2}$ refers to the $R^{2}$ from estimation of equation (5). $R_{\beta_{2}}^{2}$ refers to the $R^{2}$ from estimation of equation (4) - this is done using estimates from a first-step of a FGLS procedure. The sample period covers 1973-2002. Estimates are calculated using a FGLS estimator, as described in Appendix B. + significant at 10\%; ${ }^{*}$ significant at 5\%; ${ }^{* *}$ significant at $1 \%$. 
Table 6. Potential Channels

\begin{tabular}{lccc}
\hline \hline & $(1)$ & $(2)$ & $(3)$ \\
& $\Delta$ Own R & Exports to Base & $\Delta$ NER \\
\hline Base R & & -0.064 & -0.120 \\
& & $(0.077)$ & $(0.213)$ \\
Base R $\times$ Peg & & $0.256+$ & -0.105 \\
& & $(0.153)$ & $(0.229)$ \\
$\Delta$ Base R & 0.172 & & \\
& $(0.216)$ & & \\
$\Delta$ Base R $\times$ Peg & $0.360^{*}$ & & \\
Peg & $(0.176)$ & & \\
& -0.011 & $-0.025+$ & $-0.070^{* *}$ \\
Inflation & $(0.009)$ & $(0.015)$ & $(0.020)$ \\
& $0.156^{* *}$ & $0.018^{* *}$ & $0.593^{* *}$ \\
Base GDP Growth & $(0.055)$ & $(0.006)$ & $(0.032)$ \\
& -0.017 & -0.002 & 0.216 \\
Observations & $(0.079)$ & $(0.061)$ & $(0.136)$ \\
$R^{2}$ & 1933 & 3236 & 3503 \\
& 0.204 & 0.573 & 0.550 \\
\hline
\end{tabular}

Notes: The table gives OLS estimates of the effect of the base country nominal interest rate on domestic nominal interest rates, export to base, and changes in the exchange rate. The sample period is 1973-2002. Country and year effects are included. Estimates in columns (1)-(4) do not include any additional controls. Robust standard errors are clustered at the country level. + significant at $10 \%$; ${ }^{*}$ significant at $5 \%$; ** significant at $1 \%$. 
Table A1. Countries in the Sample

\begin{tabular}{|c|c|c|c|}
\hline Afghanistan, I.S. of ${ }^{8}$ & Czech Republic $^{4}$ & Kuwait $^{8}$ & Poland $^{4}$ \\
\hline Albania $^{4}$ & Denmark $^{4}$ & Kyrgyz Republic $^{8}$ & Portugal $^{4}$ \\
\hline Algeria $^{3}$ & Djibouti $^{8}$ & Lao People's Dem. Rep. ${ }^{8}$ & Romania $^{8}$ \\
\hline Angola $^{8}$ & Dominican Republic ${ }^{8}$ & Latvia $^{8}$ & Russia $^{8}$ \\
\hline Argentina $^{8}$ & Ecuador $^{8}$ & Lebanon $^{8}$ & Rwanda $^{8}$ \\
\hline Armenia $^{8}$ & Egypt $^{8}$ & Lesotho $^{10}$ & Saudi Arabia $^{8}$ \\
\hline Australia $^{8}$ & El Salvador ${ }^{8}$ & Liberia $^{8}$ & Senegal $^{3}$ \\
\hline Austria $^{4}$ & Equatorial Guinea $^{3}$ & Libya $^{8}$ & Sierra Leone ${ }^{8,9}$ \\
\hline Azerbaijan $^{8}$ & Estonia $^{4}$ & Lithuania $^{12}$ & Singapore $^{6}$ \\
\hline Bahamas, The ${ }^{8}$ & Ethiopia $^{8}$ & Luxembourg $^{2}$ & Slovak Republic ${ }^{4}$ \\
\hline Bahrain $^{8}$ & $\mathrm{Fiji}^{8,9}$ & Macedonia, $\mathrm{FYR}^{4}$ & Slovenia $^{4}$ \\
\hline Bangladesh $^{8,9}$ & Finland $^{4}$ & Madagascar $^{3}$ & Solomon Islands ${ }^{9}$ \\
\hline Barbados $^{8,9}$ & France $^{4}$ & Malawi $^{8}$ & Somalia $^{8}$ \\
\hline Belarus $^{8}$ & Gabon $^{3}$ & Malaysia $^{8}$ & South Africa ${ }^{8}$ \\
\hline Belgium $^{4}$ & Gambia, The $\mathrm{T}^{8,9}$ & Maldives $^{8}$ & Spain $^{4}$ \\
\hline Benin $^{3}$ & Georgia $^{8}$ & Mali $^{3}$ & Sri Lanka ${ }^{5,8,9}$ \\
\hline Bhutan $^{5}$ & Germany $^{8}$ & Malta $^{3}$ & Sudan $^{8}$ \\
\hline Bolivia $^{8}$ & Ghana $^{8}$ & Mauritania $^{3,8}$ & Suriname $^{8}$ \\
\hline Bosnia \& Herzegovina ${ }^{4}$ & Greece $^{4,8}$ & Mauritius $^{9}$ & Swaziland $^{10}$ \\
\hline Botswana $^{8,10}$ & Guatemala $^{8}$ & Mexico $^{8}$ & Sweden $^{4}$ \\
\hline Brazil $^{8}$ & Guinea $^{8}$ & Moldova $^{8}$ & Switzerland $^{4}$ \\
\hline Bulgaria $^{4,8}$ & Guinea-Bissau $^{3,7}$ & Mongolia $^{8}$ & Syrian Arab Rep. ${ }^{8}$ \\
\hline Burkina Faso $^{3}$ & Guyana $^{8,9}$ & Morocco $^{3}$ & Tajikistan $^{8}$ \\
\hline Burundi $^{8}$ & Haiti $^{8}$ & Mozambique $^{8}$ & Tanzania $^{8}$ \\
\hline Cameroon $^{3}$ & Honduras $^{8}$ & Myanmar $^{8}$ & Thailand $^{8}$ \\
\hline Canada $^{8}$ & Hungary $^{4,8}$ & Namibia $^{10}$ & $\operatorname{Togo}^{3}$ \\
\hline Cape Verde ${ }^{7}$ & Iceland $^{4,8}$ & $\mathrm{Nepal}^{5,8}$ & Trinidad \& Tobago ${ }^{8,9}$ \\
\hline Central African Rep. ${ }^{3}$ & India $^{8,9}$ & Netherlands ${ }^{4}$ & Tunisia $^{3}$ \\
\hline $\mathrm{Chad}^{3}$ & Indonesia $^{8}$ & New Zealand ${ }^{1}$ & Turkey $^{8}$ \\
\hline Chile $^{8}$ & Iran, I.R. of ${ }^{8}$ & Nicaragua $^{8}$ & Turkmenistan 8 \\
\hline China, People's Rep. ${ }^{8}$ & $\operatorname{Iraq}^{8}$ & Niger $^{3}$ & Uganda $^{8}$ \\
\hline China, P.R.: Hong Kong ${ }^{8}$ & Ireland $^{4,9}$ & Nigeria $^{8}$ & Ukraine $^{8}$ \\
\hline Colombia $^{8}$ & Israel $^{8}$ & Norway $^{4}$ & United Arab Emirates ${ }^{8}$ \\
\hline Comoros $^{3}$ & Italy $^{4}$ & $\mathrm{Oman}^{8}$ & United Kingdom ${ }^{4}$ \\
\hline Congo, Democratic Rep. of ${ }^{8}$ & Jamaica $^{8}$ & Pakistan $^{8}$ & Uruguay $^{8}$ \\
\hline Congo, Republic of ${ }^{3}$ & Japan $^{8}$ & Panama $^{8}$ & Venezuela $^{8}$ \\
\hline Costa Rica ${ }^{8}$ & Jordan $^{8}$ & Papua New Guinea $^{9}$ & Vietnam $^{8}$ \\
\hline Côte d'Ivoire ${ }^{3}$ & Kazakhstan $^{8}$ & Paraguay $^{8}$ & Yemen $^{8}$ \\
\hline Croatia $^{4}$ & Kenya $^{8}$ & $\mathrm{Peru}^{8}$ & Zambia $^{8}$ \\
\hline Cyprus $^{3}$ & Korea $^{8}$ & Philippines $^{8}$ & Zimbabwe $^{8}$ \\
\hline \multicolumn{4}{|c|}{ Base Countries } \\
\hline Australia (1) & Germany (4) & Portugal (7) & South Africa (10) \\
\hline Belgium (2) & India $(5)$ & United States (8) & \\
\hline France (3) & Malaysia (6) & United Kingdom (9) & \\
\hline
\end{tabular}

Notes: Superscript refers to base country. A country may have multiple bases over the sample period. Furthermore, all base countries, except for the United States, have a base country. Approximately $60 \%$ of the countries in the sample have the U.S. as a base vs. $40 \%$ that are non-U.S. based. 
Table A2. Sample Summary Statistics

\begin{tabular}{lccc}
\hline \hline & Full & Pegs & Nonpegs \\
\hline Observations & 3831 & 1753 & 2078 \\
Mean GDP Growth & 0.033 & 0.033 & 0.033 \\
Std Dev GDP Growth & 0.047 & 0.052 & 0.043 \\
Mean Base R & 0.072 & 0.075 & 0.070 \\
Std Dev Base R & 0.034 & 0.036 & 0.033 \\
\hline
\end{tabular}

Notes: Data summarized reflect the sample used in estimation of the baseline results in Table 1. The sample period is 1973-2002. 


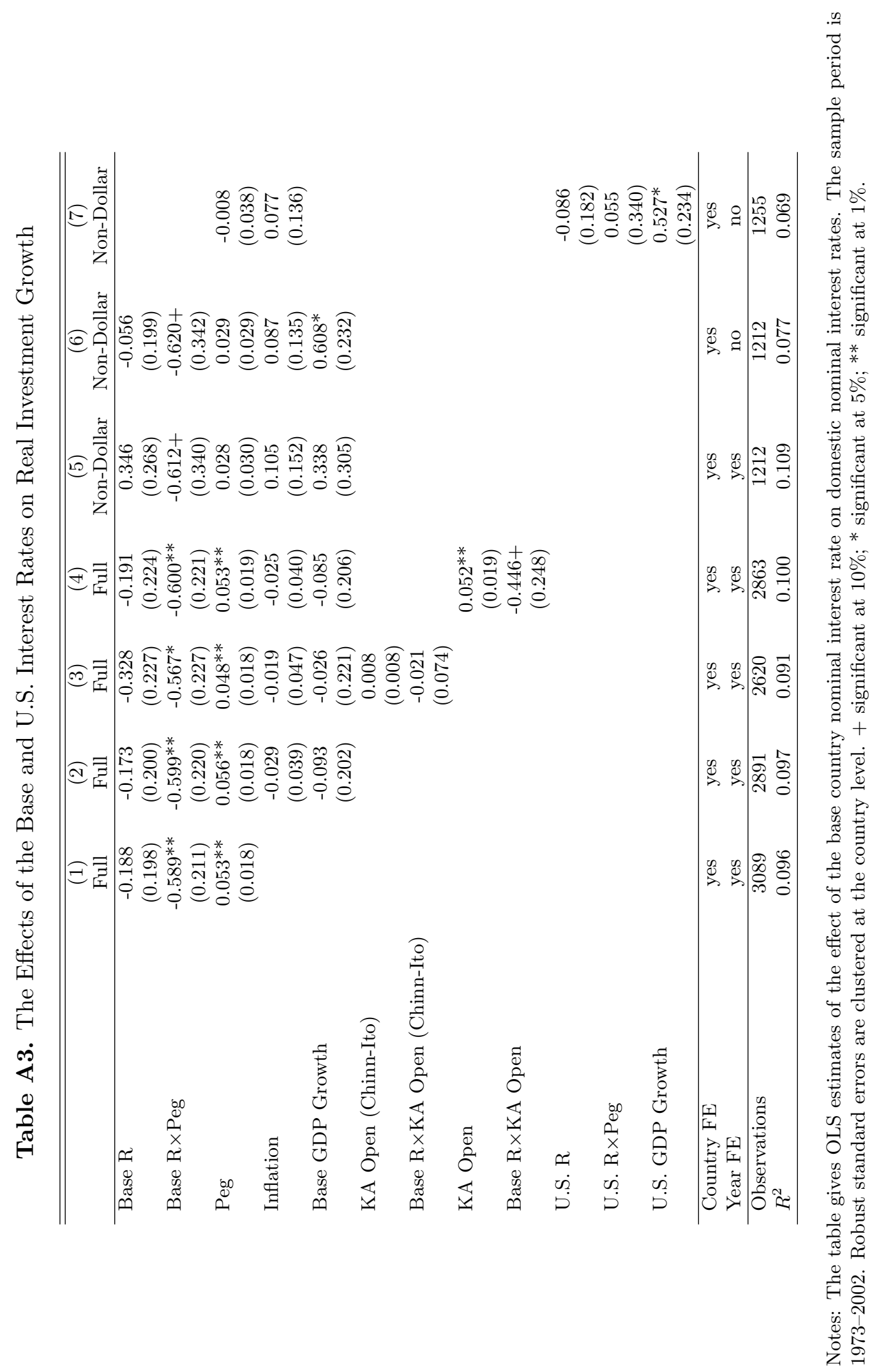


Table A4. Different Cuts of the Data to Exclude Outlier Periods and Observations

\begin{tabular}{lcccccc}
\hline \hline & $(1)$ & $(2)$ & $(3)$ & $(4)$ & $(5)$ & $(6)$ \\
& & No & No & No Free & No & \\
& Full & Transition & Crisis & Fall & Bases & Cut $10 \%$ \\
\hline Base R & -0.014 & -0.029 & -0.036 & -0.002 & -0.018 & 0.007 \\
& $(0.046)$ & $(0.051)$ & $(0.045)$ & $(0.045)$ & $(0.049)$ & $(0.054)$ \\
Base R×Peg & $-0.174^{* *}$ & $-0.157^{* *}$ & $-0.159^{* *}$ & $-0.193^{* *}$ & $-0.180^{* *}$ & $-0.189^{* *}$ \\
& $(0.050)$ & $(0.058)$ & $(0.050)$ & $(0.051)$ & $(0.052)$ & $(0.053)$ \\
Peg & $0.011^{* *}$ & 0.008 & $0.009^{*}$ & $0.013^{* *}$ & $0.012^{* *}$ & $0.013^{* *}$ \\
& $(0.004)$ & $(0.005)$ & $(0.004)$ & $(0.004)$ & $(0.005)$ & $(0.005)$ \\
Inflation & $-0.029^{* *}$ & $-0.025^{* *}$ & $-0.025^{* *}$ & -0.011 & $-0.029^{* *}$ & $-0.030^{* *}$ \\
\multirow{5}{*}{ Base GDP Growth } & $(0.007)$ & $(0.007)$ & $(0.008)$ & $(0.013)$ & $(0.007)$ & $(0.007)$ \\
& 0.113 & 0.093 & 0.115 & $0.136+$ & 0.107 & 0.077 \\
\hline Observations & $(0.076)$ & $(0.081)$ & $(0.078)$ & $(0.076)$ & $(0.080)$ & $(0.075)$ \\
$R^{2}$ & 3419 & 2938 & 3212 & 3129 & 3169 & 3020 \\
\hline
\end{tabular}

Notes: The table gives OLS estimates of the effect of the base country nominal interest rate on domestic nominal interest rates. The sample period is 1973-2002. Country and year effects are included. "No Transition" refers to periods where a country moves from peg to float or vice versa. In this case, the year before pegging the first year of pegging, the last year of pegging and the first year after pegging are all dropped. "Crisis" is based on the definition suggested by Frankel and Rose (1996): any year where depreciation is greater than $25 \%$ and is at least $10 \%$ more than the previous year's depreciation. "Free Fall" refers to observations deemed to be freely falling (large depreciation and high inflation) by Reinhart and Rogoff. "No Bases" drops base countries from the analysis. The U.S. is automatically dropped in all regressions, but, other bases, such as France, are both a base country for some other countries and a domestic country (with Germany as the base). "Cut 10\%" refers to cutting large countries, as defined as countries with GDP at least $10 \%$ of base country GDP. Robust standard errors are clustered at the country level. + significant at $10 \% ;{ }^{*}$ significant at $5 \%$; $* *$ significant at $1 \%$. 


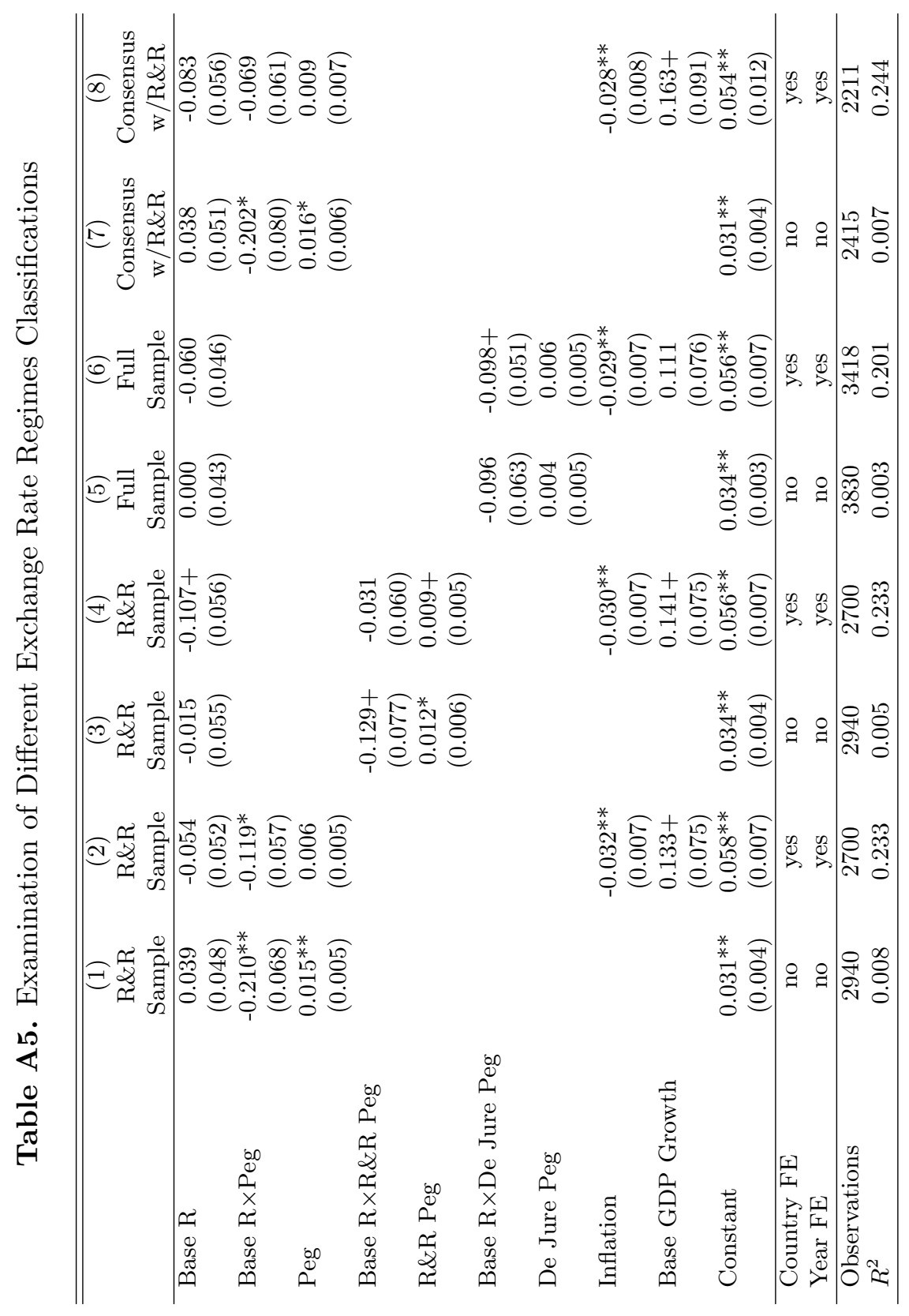

.

चै

제

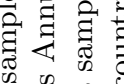

Q

.

ญे

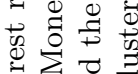

记

羟

范泀贾

过

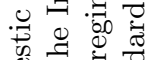

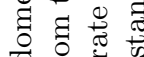

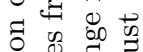

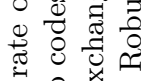

웅.

造离

ฮี

త్తే

○्व

है

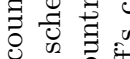

ऽ. 워

萬

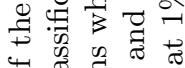

岁㤎

䒴的.

$\circ$ o d

च्ञ 제

㟧

क

주

㻤

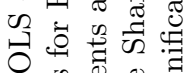

पु

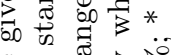
궁 If 2 \& ษ

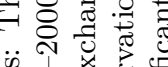

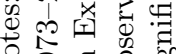

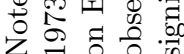




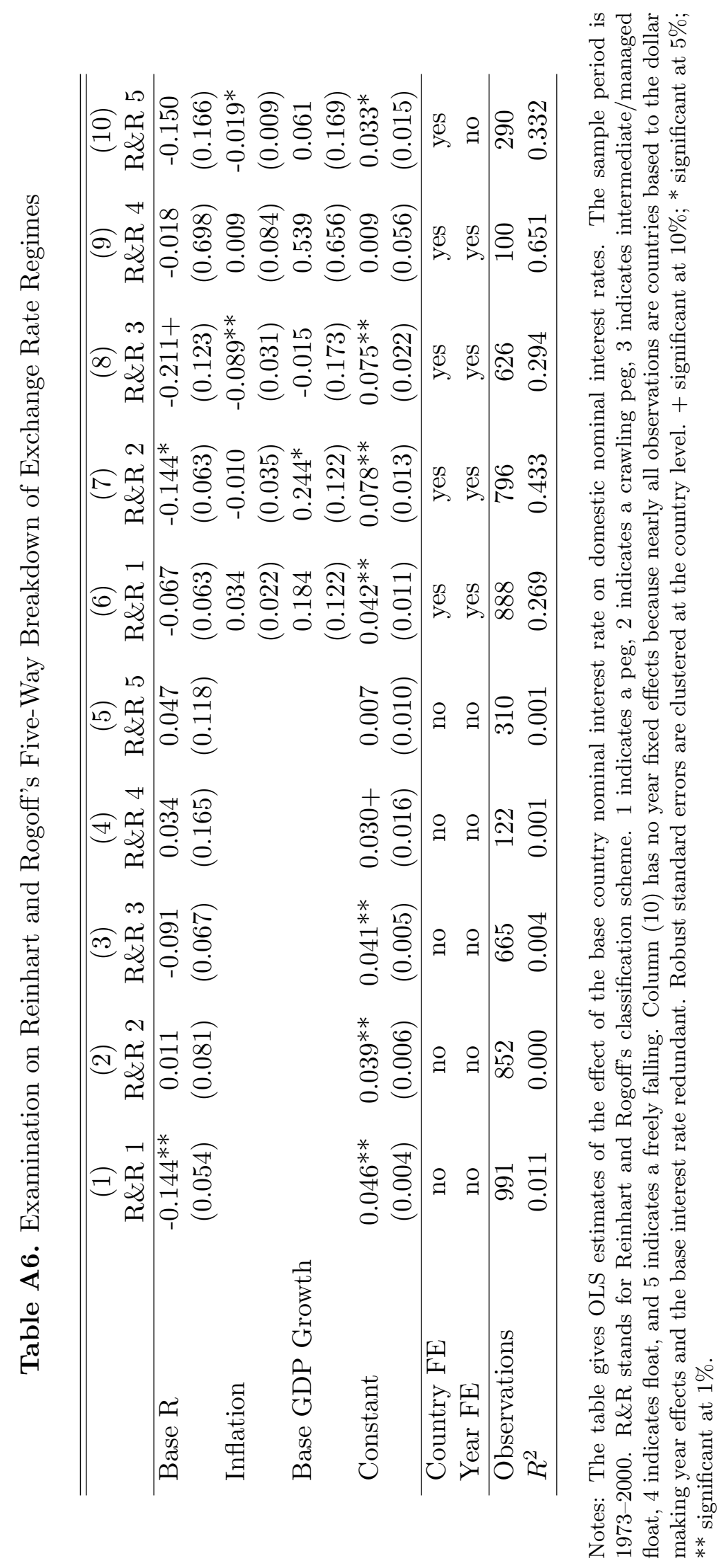


Table A7. Core Regressions on Trimmed Sample

\begin{tabular}{lccccc}
\hline \hline & $(1)$ & $(2)$ & $(3)$ & $(4)$ & $(5)$ \\
& Core & $\begin{array}{c}\text { Drop 100\% Peg } \\
\text { and Nonpeg }\end{array}$ & $\begin{array}{c}\text { Prop. Score } \\
\text { Available }\end{array}$ & $\begin{array}{c}5 \text { th Pctile } \\
\text { Trim }\end{array}$ & $\begin{array}{c}\text { 1st Pctile } \\
\text { Trim }\end{array}$ \\
\hline Base R & -0.014 & -0.003 & -0.04 & -0.088 & -0.063 \\
Base R $\times$ Peg & $(0.045)$ & $(0.053)$ & $(0.054)$ & $(0.060)$ & $(0.055)$ \\
& $-0.174^{* *}$ & $-0.209^{* *}$ & $-0.172^{* *}$ & $-0.138^{*}$ & $-0.155^{* *}$ \\
Peg & $(0.049)$ & $(0.063)$ & $(0.054)$ & $(0.062)$ & $(0.053)$ \\
& $0.011^{* *}$ & $0.014^{* *}$ & $0.011^{*}$ & $0.008+$ & $0.009^{*}$ \\
Inflation & $(0.004)$ & $(0.005)$ & $(0.004)$ & $(0.005)$ & $(0.004)$ \\
& 0.113 & 0.112 & 0.11 & $0.139+$ & $0.140+$ \\
Base GDP Growth & $-0.029^{* *}$ & $-0.036^{* *}$ & $-0.033^{* *}$ & $-0.027^{* *}$ & $-0.031^{* *}$ \\
& $(0.007)$ & $(0.009)$ & $(0.008)$ & $(0.009)$ & $(0.008)$ \\
\hline Observations & 3419 & 2334 & 3017 & 2325 & 2825 \\
$R^{2}$ & 0.204 & 0.24 & 0.194 & 0.203 & 0.199 \\
\hline
\end{tabular}

Notes: The table gives OLS estimates of the effect of the base country nominal interest rate on annual real economic growth. The sample period is 1973-2002. Country and year effects are included. Robust standard errors are clustered at the country level. + significant at $10 \% ;{ }^{*}$ significant at $5 \%$; ${ }^{*}$ significant at $1 \%$. 
Table A8. Probability Models to Generate Propensity scores

\begin{tabular}{lcc}
\hline \hline & $(1)$ & $(2)$ \\
& OLS & Probit \\
\hline Govt share of economy & 0.004 & 0.010 \\
& $(0.005)$ & $(0.013)$ \\
Bank Credit to GDP & -0.001 & -0.003 \\
& $(0.001)$ & $(0.002)$ \\
Fuel share of exports & $0.003^{*}$ & $0.008^{*}$ \\
& $(0.001)$ & $(0.004)$ \\
Distance to base & $-0.000^{* *}$ & $-0.000^{* *}$ \\
& $(0.000)$ & $(0.000)$ \\
GDP (in dollars) & 0.000 & 0.000 \\
& $(0.000)$ & $(0.000)$ \\
Real GDP per capita & $-0.000+$ & $-0.000+$ \\
Capital controls & $(0.000)$ & $(0.000)$ \\
& $-0.129^{*}$ & $-0.373^{*}$ \\
Trade to GDP & $(0.064)$ & $(0.175)$ \\
& 0.115 & 0.313 \\
Exports to base / GDP & $(0.099)$ & $(0.269)$ \\
& -0.151 & -0.425 \\
Constant & $(0.338)$ & $(0.919)$ \\
& $0.775^{* *}$ & $0.794^{*}$ \\
\hline Observations & $(0.118)$ & $(0.333)$ \\
$R^{2}$ & 3017 & 3017 \\
\hline
\end{tabular}

Notes: The table gives OLS and Probit estimates of the probability of a country pegging to a given base country. The sample period is 1973-2002. Year effects are included. Robust standard errors are clustered at the country level. + significant at $10 \% ;{ }^{*}$ significant at $5 \% ; * *$ significant at $1 \%$. 
Figure 1. The Impact of the Exchange Rate Regime on the Estimated Base Interest Rate Coefficients

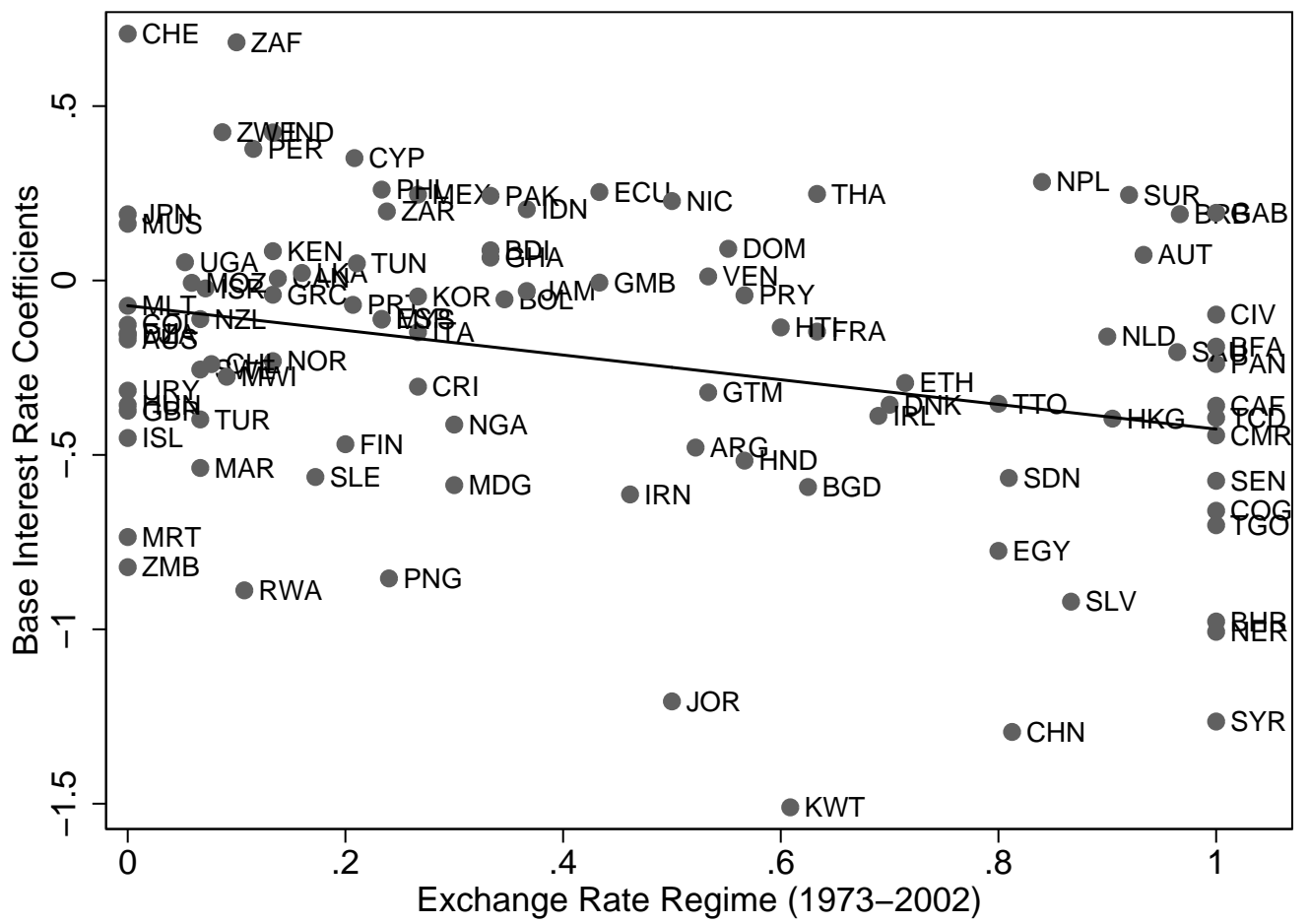

Notes: This figure plots the estimated impact of the base interest rate $\left(\widehat{\beta}_{2 i}\right)$ from running regression (3) against the average of the Peg indicator over the sample period for each country. 
Figure A1. Densities of Probability of Pegging for Pegs and Floats (Probit Exercise)

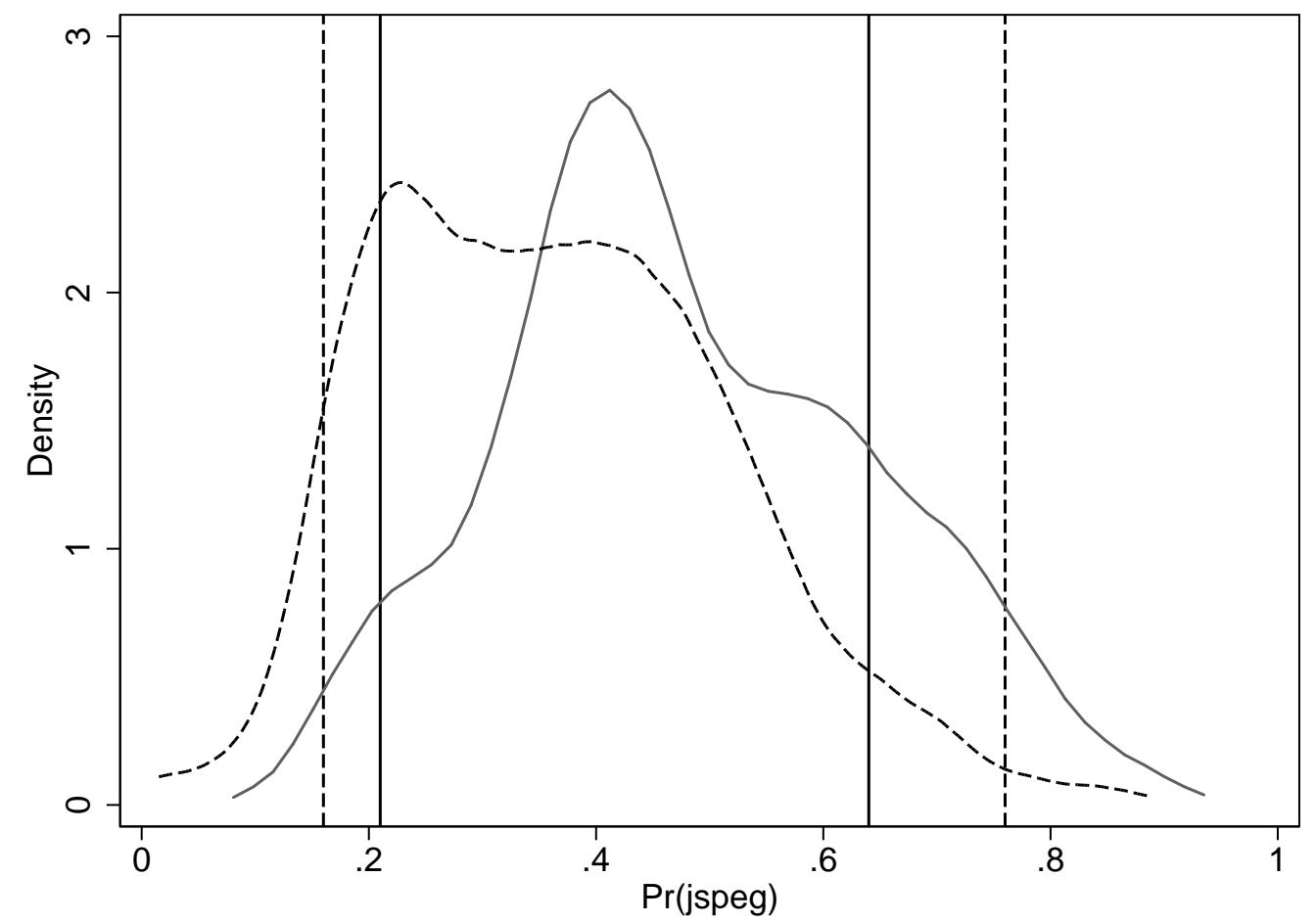

Notes: This figure plots the probability densities of either pegging or not pegging. Dashed line: density for nonpegs solid line: density for pegs dashed vertical lines represent $1 \%$ trimming points solid vertical lines represent $5 \%$ trimming points. 